\title{
MECHANICAL PROPERTIES OF LIGHTWEIGHT TREATED SOIL CURED IN WATER PRESSURE
}

\author{
TAKAShi Tsuchida ${ }^{\mathrm{i})}$, Yi XIN TANG ${ }^{\mathrm{ii})}$ and YoIchI Watabe ${ }^{\mathrm{iii}}$
}

\begin{abstract}
An artificial lightweight soil has been developed as a backfill to reduce the earth pressure behind port and harbor structures. To reduce the unit weight lightening ingredient such as air foam or EPS beads is mixed within slurry of dredged soft clay, while cement is used as stabilizer to warrant compressive strength. This experimental study aims to characterize the strength and deformation properties of lightweight treated soil cured in water pressure. Samples of two types of lightweight treated soil mixed with air foam or EPS were cured under various pressures, and subjected to undrained shearing tests on triaxial apparatus modified to detect volumetric change. Though high pressures inevitably compress lightener and consequently incur increment in unit weight, pressured curing did not reduce the compressive strength, $q_{\max }=\left(\sigma_{\mathrm{a}}-\sigma_{\mathrm{c}}\right)_{\max }$. It was also found that the deformation modulus $E_{50}$ greatly decreases with relative confining pressure $\sigma_{\mathrm{c}} / q_{\max }$. The lightweight soils maintained relatively large residual strengths, showing no significant sign of brittle failure as often confronted in unconfined compression test. It was observed that the critical state line exists when subjected to ultimate strains, and that the peak deviator stress envelop was identified in effective stress path plane for air foam mixed cases alone. $K_{0}$-consolidation tests were conducted on modified triaxial apparatus, showing that $K_{0}$ values from the quasi one dimensional tests decline to as small as 0.1 to 0.15 around axial strain of $0.5 \sim 1 \%$ at near yielding points. Poisson's ratios based on both undrained shearing and $K_{0}$-consolidation are compared in consistent tendency with minimal values of 0.1 to 0.2 near the identical yielding points. Yet it is revealed from the obtained compression curves that the compressibility increases drastically by some 100 -fold when comparing before and after yielding for lightweight treated soil. This fact strikes the importance of not overloading lightweight treated soil by its compressive strength.
\end{abstract}

Key words: harbor, lightweight soil, modulus of deformation, poisson's ratio, shear strength, water pressure (IGC: D5/D10)

\section{INTRODUCTION}

Lightweight treated soil is a new technique developed to control unit weight and shear strength as desired, and to make beneficial reuse of surplus soil at the same time. Generally, unit weight of source soil is reduced by mixing air foam or expended polystrol (EPS) beads in a proper proportion, while shear strength is warranted by use of stabilizer agent, such as cement. Although it is not difficult to lighten unit weight of the treated soil fairly lower than $10 \mathrm{kN} / \mathrm{m}^{3}$, it is usually designed somewhat at $11 \mathrm{kN} / \mathrm{m}^{3}$ or $12 \mathrm{kN} / \mathrm{m}^{3}$ so as to prevent lightened soil from buoying up in coastal areas. Unconfined compression strength ranging from $200 \mathrm{kN} / \mathrm{m}^{2}$ to $400 \mathrm{kN} / \mathrm{m}^{2}$ of this geomaterial is found conventionally sufficient for reclamation or backfill uses (Tsuchida and Takeuchi, 1996; Tsuchida, 1999; Tsuchida and Kang, 2002).

Since lightweight treated soil can directly reduce consolidation settlement, make structure more stable, and decrease earth pressure behind, this new technique is very useful for port and harbor structures which are often planned upon soft grounds. Satoh et al. (2001) showed that proper utilization of lightweight treated soil could greatly reduce the expenditure on ground improvement. Figure 1(a) exemplifies a typical wharf section planned by traditional design method. Due to the thick clay layer beneath, ground improvement needs to be conducted at a high replacement ratio of $80 \%$ with sand compaction piles, and concrete caisson should be as wide as $17 \mathrm{~m}$. However, if lightweight treated soil is introduced to substitute the original backfill stone as shown in Fig. 1(b), replacement ratio of sand compaction piles can be decreased from $80 \%$ to $30 \%$ with a little expansion of improving area, and accompanied with a significant reduction of caisson width from $17 \mathrm{~m}$ to $10 \mathrm{~m}$. As a result, total construction cost was estimated to be decreased by $32 \%$, if the new technique is applied in this planning case. In addition, indirect benefit of the new technique is related

i) Hiroshima University, Japan (ttuchida@hiroshima-u.ac.jp).

ii) Kanmon Kowan Construction Co. Ltd., Japan.

iii) Part and Airport Research Institute, Japan.

The manuscript for this paper was received for review on July 10, 2006; approved on March 26, 2007.

Written discussions on this paper should be submitted before March 1, 2008 to the Japanese Geotechnical Society, 4-38-2, Sengoku, Bunkyo$\mathrm{ku}$, Tokyo 112-0011, Japan. Upon request the closing date may be extended one month. 


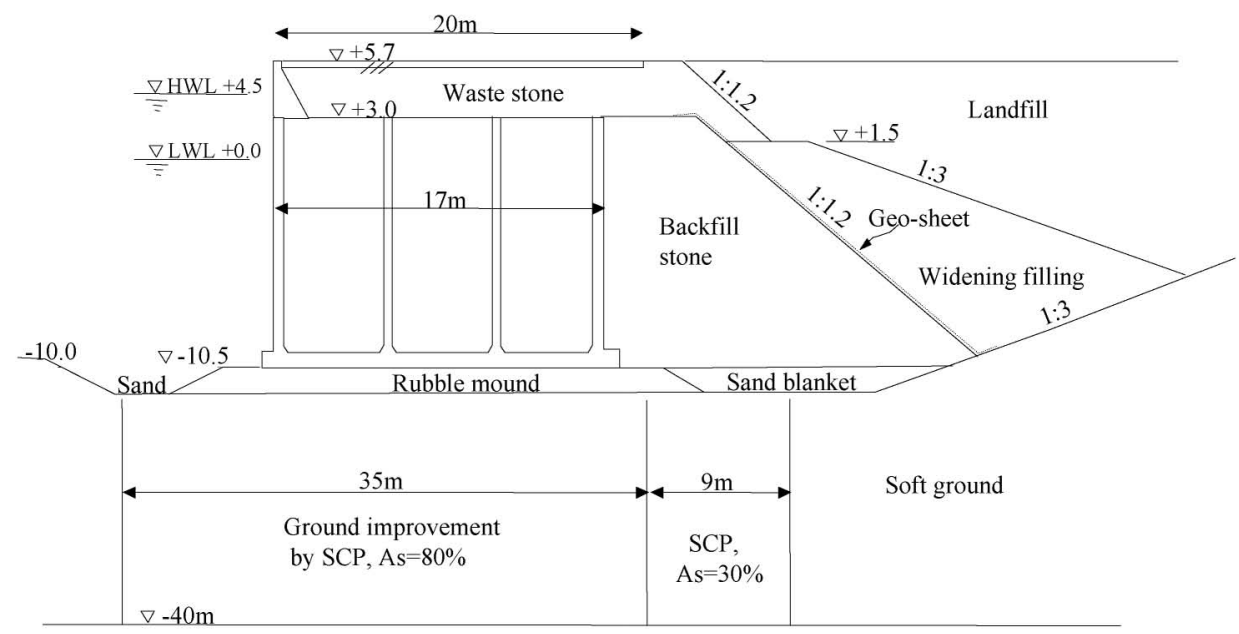

(a) Original wharf section (construction cost estimated by 22 mil. yen / m)

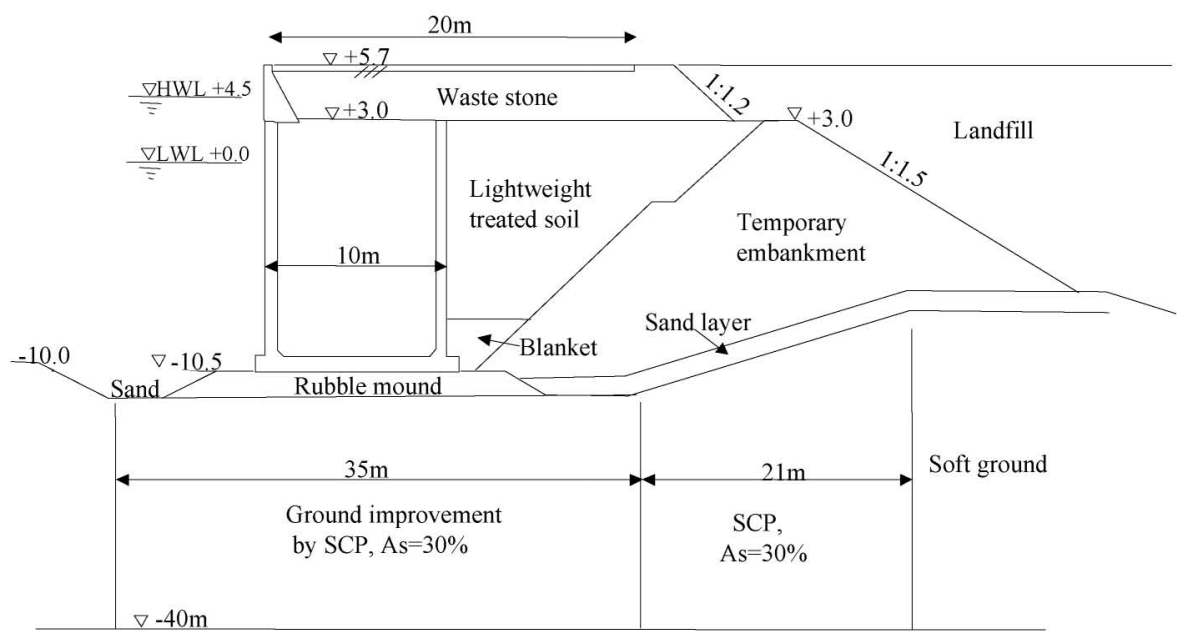

(b) Newly designed wharf section (construction cost estimated by 15 mil. yen / m)

Fig. 1. A typical wharf section feasible to application of lightweight treated soil

to effective reuse of surplus soil. It is particularly attractive to coastal engineers, since wide applications of lightweight treated soil will lead to a large quantity consumption of dredged clayey soil.

It is a fact that unit cost for lightweight treated soil is higher than that of conventional geo-materials. Considering the total construction cost, it becomes important to use the minimum volume of lightweight treated soil in an optimal design. To provide routine tool for design works, Tsuchida et al. (1999) proposed a method to calculate earth pressure where traditional backfill is supposed to be replaced by lightweight treated soil.

As shown in Fig. 1, lightweight treated soil is most likely to be deployed underwater as deep as $10 \mathrm{~m}$. Whether or not it should exhibit peculiar behaviors due to large water pressure turns to be an important subject, because it is a mixture made of compressible air foam or EPS beads. The aim of the present experimental investigation was to characterize the strength and deformation properties of lightweight treated soil, especially when it is deployed un- der water pressure conditions. Conventional triaxial apparatus is modified to measure volumetric change when specimen of lightweight treated soil is subjected to compression and shearing deformation. A series of lightweight treated samples were prepared on basis of dredged clay, and lighteners of both air foam and EPS beads were used in the experimental program. These specimens were cured under water pressure within sealed container, and then unconsolidated undrained compression tests were carried out on the modified apparatus. Beside that, $K_{0}$ controlled consolidation tests were also performed on the humid atmosphere cured ones, by use of the same modified apparatus.

\section{TEST APPARATUS AND SAMPLES}

Lightweight treated soil consists of compressive lightening material, air foam or EPS beads and behaves like unsaturated soil even though it is prepared and sheared under saturated condition. Even set in undrained states, 
the samples are prospectively to exhibit volumetric changes when they are subjected to isotropic compression or shearing. Here, the artificial geomaterial is regarded as saturated soil because its fundamental soil is dredged from seabed, and prepared as slurry. After mixed with cement and lightening material it is supposed to be placed underwater. So it is believed there is no suction effect on strength property in spite of remarkable compressibility. To study its deformation behavior, it is necessary to perform triaxial tests with outer measurement device of volumetric change. For this purpose, conventional triaxial apparatus was modified as shown in Fig. 2, where an acryl cylinder peripheral to the specimen was mounted inside the triaxial cell. Volumetric change of specimen was measured by monitoring water level of the inner cell by a differential pressure gauge.

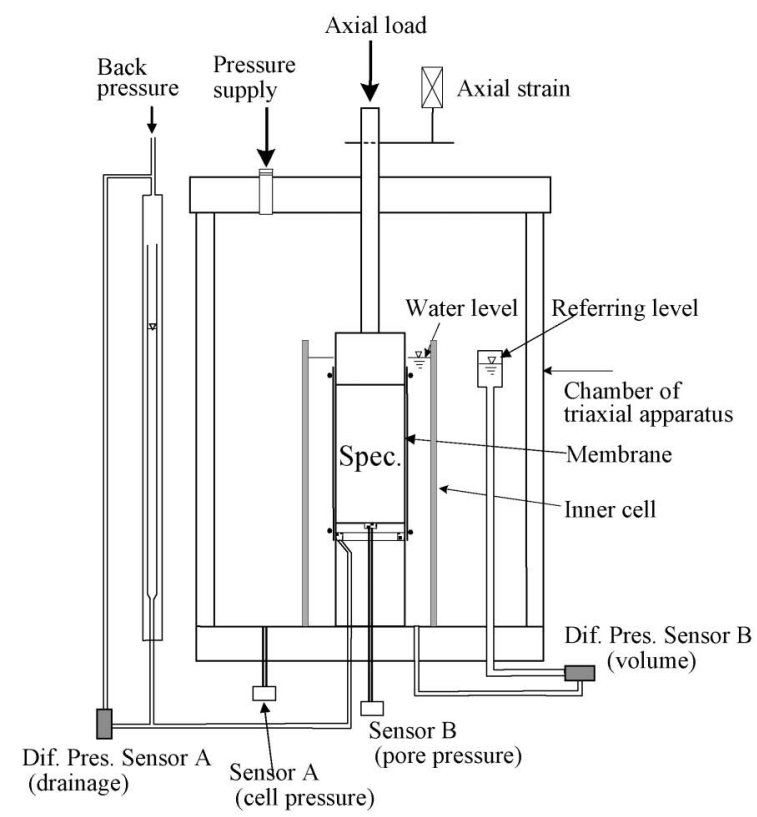

Fig. 2. Modified triaxial apparatus

\section{Ingredients}

Basically, lightweight treated soil is a compound of original soil, lightening material and cement. The soil used was dredged clay from Kawasaki port with its physical properties shown in Table 1. Following the precedent studies in relation to workability concerns such as feasibilities of mixing and pumping transportation, properties of underwater separation resistance, air foam disappearance resistance (Tsuchida et al., 1997a; Tsuchida et al., 1997b), the water content soil of Kawasaki clay was adjusted to 2.5 times the water content of liquid limit, $w_{\mathrm{L}}$ for air foam mixture, and $2.2 w_{\mathrm{L}}$ for EPS beads mixture. During the preparation of original soil, the grainy particles were removed, prior to the test.

To generate air foam, surface-active agent (Finefoam606) was diluted with fresh water by 10 times, and the dilution was further expanded to 20 folds through compressed air of $200 \mathrm{kPa}$. EPS beads with expansion rate of 30, 50, 70 folds was produced in factory. Mean diameter and densities of beads are given in Table 2. Blast furnace slag cement B type was used as a stabilizer. Its specific gravity is about 3.05 .

Table 1. Physical properties of Kawasaki clay

\begin{tabular}{l|c|c|c|c}
\hline \multirow{2}{*}{$\begin{array}{l}\text { Physical } \\
\text { index }\end{array}$} & $\begin{array}{c}\text { Grain } \\
\text { density }\end{array}$ & $\begin{array}{c}\text { Liquid } \\
\text { limit }\end{array}$ & $\begin{array}{c}\text { Plastic } \\
\text { limit }\end{array}$ & $\begin{array}{c}\text { Plasticity } \\
\text { index }\end{array}$ \\
\cline { 2 - 5 } & $25.8 \mathrm{kN} / \mathrm{m}^{3}$ & $76.1 \%$ & $45.8 \%$ & 31.3 \\
\hline \multirow{2}{*}{$\begin{array}{l}\text { Grain } \\
\text { gradation }\end{array}$} & $\begin{array}{c}\text { Coarse } \\
\text { grain }\end{array}$ & Sand & Silt & Clay \\
\cline { 2 - 5 } & $0.3 \%$ & $6.6 \%$ & $77.1 \%$ & $16.0 \%$ \\
\hline
\end{tabular}

Table 2. Densities and grain size of EPS beads

\begin{tabular}{l|l|l|l}
\hline Expansion rate (fold) & 30 & 50 & 70 \\
\hline Superficial density $\left(\mathrm{kN} / \mathrm{m}^{3}\right)$ & 0.33 & 0.20 & 0.14 \\
\hline Beads' density $\left(\mathrm{kN} / \mathrm{m}^{3}\right)$ & 0.52 & 0.31 & 0.22 \\
\hline Mean diameter $(\mathrm{mm})$ & 2.4 & 2.0 & 2.0 \\
\hline
\end{tabular}

Table 3. Designed proportions and pressured curing condition

\begin{tabular}{|c|c|c|c|c|c|c|c|c|c|}
\hline \multirow{2}{*}{$\begin{array}{l}\text { Lightweight } \\
\text { treating type }\end{array}$} & \multirow{2}{*}{$\begin{array}{c}\text { Target } \\
\text { Strength } \\
q_{\mathrm{u}}\left(\mathrm{kN} / \mathrm{m}^{2}\right)\end{array}$} & \multicolumn{3}{|c|}{ Source soil } & \multicolumn{2}{|c|}{ Cement } & \multicolumn{2}{|c|}{ Lightener } & \multirow{2}{*}{$\begin{array}{l}\text { Curing } \\
\text { pressure } \\
\left(\mathrm{kN} / \mathrm{m}^{2}\right)\end{array}$} \\
\hline & & $\begin{array}{c}\text { Water } \\
\text { cont. } w(\%)\end{array}$ & $\begin{array}{l}\text { Weight } \\
(\mathrm{kN})\end{array}$ & $\begin{array}{l}\text { Volume } \\
\quad(l)\end{array}$ & $\begin{array}{l}\text { Weight } \\
(\mathrm{kN})\end{array}$ & $\begin{array}{l}\text { Volume } \\
\quad(l)\end{array}$ & $\begin{array}{l}\text { Weight } \\
(\mathrm{kN})\end{array}$ & $\begin{array}{l}\text { Volume } \\
\qquad(l)\end{array}$ & \\
\hline \multirow{2}{*}{$\begin{array}{l}\text { Air foam } \\
\text { mixed }\end{array}$} & 200 & 186 & 11.33 & 896 & 0.66 & 21 & 0.04 & 83 & \multirow{2}{*}{$\begin{array}{r}50,100 \\
200,300\end{array}$} \\
\hline & 400 & 186 & 11.24 & 888 & 0.76 & 25 & 0.04 & 87 & \\
\hline \multirow{2}{*}{$\begin{array}{l}\text { 30-fold EPS } \\
\text { beads mixed }\end{array}$} & 200 & 164 & 11.37 & 879 & 0.63 & 21 & 0.05 & 100 & \multirow{2}{*}{300 only } \\
\hline & 400 & 164 & 11.28 & 872 & 0.72 & 24 & 0.05 & 104 & \\
\hline \multirow{2}{*}{$\begin{array}{l}50 \text {-fold EPS } \\
\text { beads mixed }\end{array}$} & 200 & 164 & 11.36 & 879 & 0.64 & 21 & 0.03 & 100 & \multirow{2}{*}{$\begin{array}{r}50,100 \\
200,300\end{array}$} \\
\hline & 400 & 164 & 11.27 & 872 & 0.73 & 24 & 0.03 & 104 & \\
\hline \multirow{2}{*}{$\begin{array}{l}70 \text {-fold EPS } \\
\text { beads mixed }\end{array}$} & 200 & 164 & 11.35 & 879 & 0.65 & 21 & 0.02 & 100 & \multirow{2}{*}{50 only } \\
\hline & 400 & 164 & 11.27 & 872 & 0.72 & 24 & 0.02 & 104 & \\
\hline
\end{tabular}




\section{Proportion Design and Mixing Method}

Unit weight of lightweight treated soil was designed at $12 \mathrm{kN} / \mathrm{m}^{3}$, with unconfined compression strength (28 days curing) targeted at $200 \mathrm{kN} / \mathrm{m}^{2}, 400 \mathrm{kN} / \mathrm{m}^{2}$, respectively. Table 3 shows designed proportion among source soil, cement and lightener. The designed proportion of lightener is calculated for the purpose to achieve an unit weight of $12 \mathrm{kN} / \mathrm{m}^{3}$, while the content of cement was determined empirically on the basis of preliminary blending tests.

Preparing procedure to create lightweight treated soil was as follows.

Arranged clay, with coarse grains removed through a 2 $\mathrm{mm}$ mesh sieve, was diluted into a slurry state with decided water content. After examination of slurry density, determined quantity of cement was mixed and agitated for 3 minutes. Immediately, pre-calculated quantity of lightener was added, and further churned for another 3 minutes in EPS beads cases, while 30 seconds in air foam cases. It was identified that the unit weight of created sample hereby met within $12 \pm 0.3 \mathrm{kN} / \mathrm{m}^{3}$ adequately. Otherwise, further adjustment was conducted by slight addition of lightener when it was greater than $12.3 \mathrm{kN} / \mathrm{m}^{3}$ or by charging a little more cement mixed slurry when it was less than $11.7 \mathrm{kN} / \mathrm{m}^{3}$.

The prepared lightweight slurry was poured into the moulds, $50 \mathrm{~mm}$ in diameter and $100 \mathrm{~mm}$ in height, to make specimens and for curing purposes.

\section{Curing Condition}

The molded samples were set inside different curing containers teemed with seawater, which were sealed and applied with different pressures $\left(p_{\text {cure }}=50,100,200,300\right.$ $\mathrm{kN} / \mathrm{m}^{2}$ respectively). Figure 3 illustrates the curing condition. Table 3 shows proportion conditions and curing pressures. Curing pressures were especially restrained at $300 \mathrm{kN} / \mathrm{m}^{2}$ for 30 -fold EPS beads cases, and at $50 \mathrm{kN} / \mathrm{m}^{2}$ for 70-fold EPS beads cases. It seems that the experimental results do not vary much from 50 -fold EPS beads cases, so the present paper mainly reports the mechanical properties for air foam mixed and 50-fold EPS beads mixed cases. The underwater pressured curing was kept for 28 days.

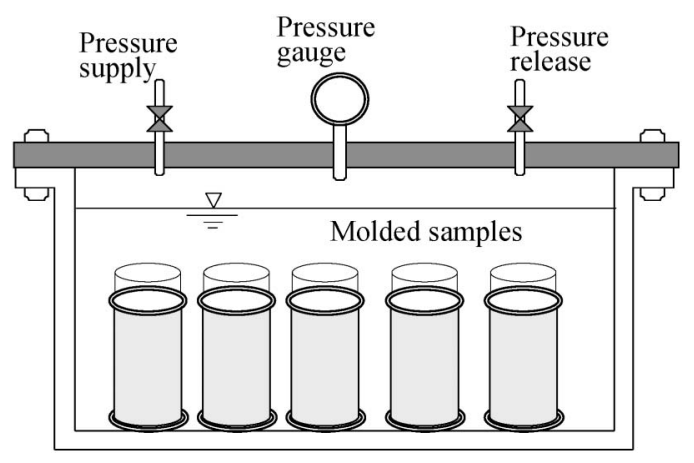

Fig. 3. Sealed container for pressured curing

\section{Unit Weight and Unconfined Compression Strength of Pressure-cured Samples}

As the lightweight treated samples were subjected to water pressure before hardening began, it was speculated that pressured curing might bring about density increase and influence unconfined compression strength. Figures 4 and 5 show the previous experimental results by Tanaka et al. (1994) and Kikuchi et al. (1994). It seems that unit weight increases gently with curing pressure increasing from 0 to $200 \mathrm{kN} / \mathrm{m}^{2}$, while unconfined compression strength remains almost unchanged for air foam lightened cases and exhibits a slight decreasing tendency for EPS beads (50-fold expansion) lightened cases.

Unconfined compression tests were also conducted on the identical samples prepared for triaxial experiments. Figure 6 shows unconfined compression strength. While there was a slight increasing tendency of unconfined compressive strength for air foam mixed samples, it seems

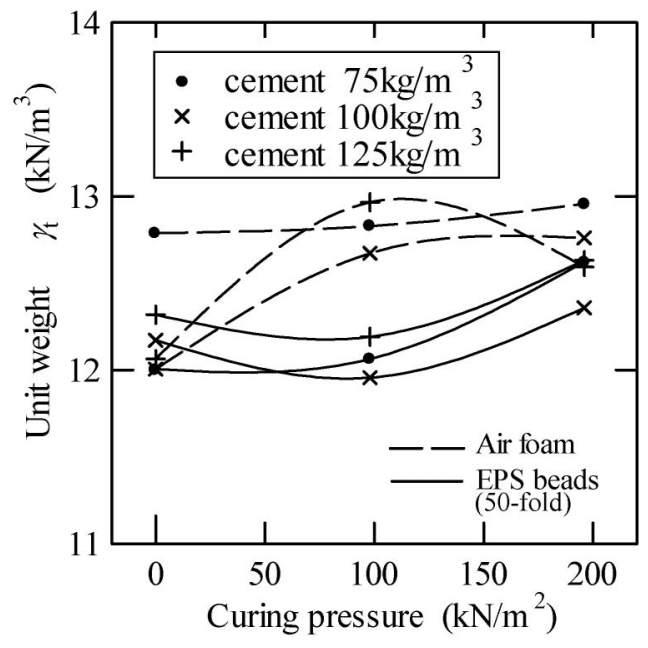

Fig. 4. Variance of unit weight due to pressured curing (after Tanaka et al. and Kikuchi et al.)

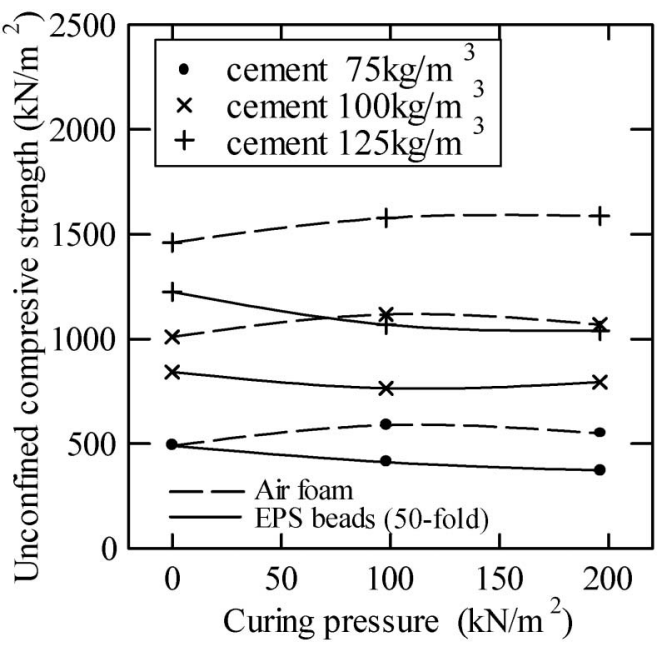

Fig. 5. Effect of pressured curing on unconfined compressive strength (after Tanaka et al. and Kikuchi et al.) 


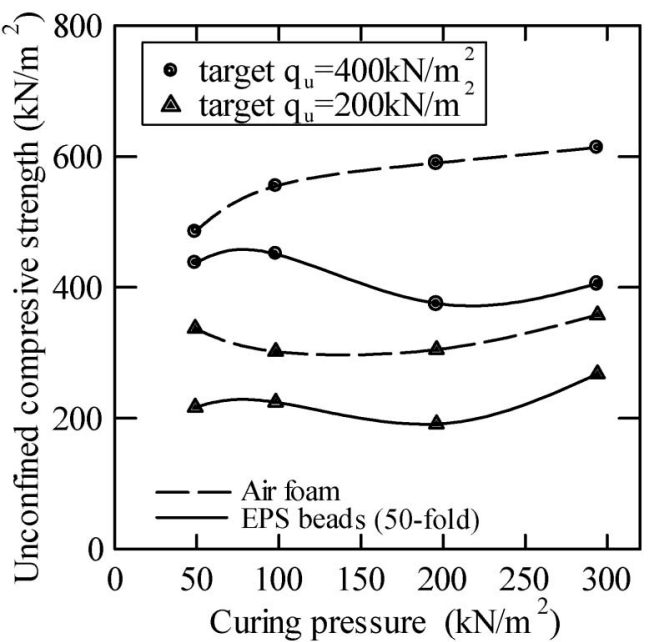

Fig. 6. Unconfined compressive strength of the samples after pressured curing ( 28 days)

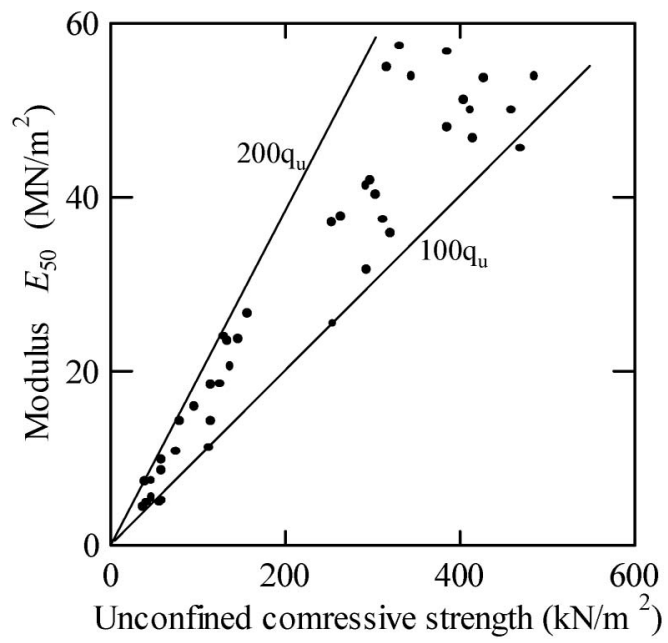

Fig. 7. Correlation between modulus $E_{50}$ and unconfined compressive strength

almost constant for EPS beads (50-fold expansion) mixed samples. The results shown in Figs. 5 and 6 are essentially in agreement with each other. Figure 7 presents the correlation between Secant modulus $E_{50}$ and unconfined compression strength $q_{\mathrm{u}}$, as is given by:

$$
E_{50}=(100 \sim 200) q_{\mathrm{u}}
$$

The above relation well agreed with the result reported by Tsuchida et al. (1996) from a field test. Such identical results suggest that pressured curing within $300 \mathrm{kN} / \mathrm{m}^{2}$ does not affect deformation modulus $E_{50}$ as long as in unconfined compression condition.

\section{UNDRAINED COMPRESSION IN TRIAXIAL APPARATUS}

\section{Pressure Released Sample}

In order to make specimens for triaxial experiments, the pressure cured samples were exposed and trimmed be- fore being set onto triaxial apparatus. When the curing pressure is released, the lightener ingredient, air foam or EPS beads, tends to expand. This situation renders extension crack across the pressure cured samples. In fact, several samples were found broken in section by being taken out of the curing container. All air foam mixed samples designed with lower strength $\left(q_{\mathrm{u}}=200 \mathrm{kN} / \mathrm{m}^{2}\right)$ and cured at greater pressure $\left(p_{\text {cure }} \geqq 100 \mathrm{kN} / \mathrm{m}^{2}\right)$ were found to be broken, but none were found broken for other cases. Such phenomenon could be interpreted that the extension strength of cured sample was not large enough to sustain expansive pressure deduced from internal air foam. In the triaxial tests, the samples, which were broken into 2 or 3 fragments, were trimmed carefully and the specimens were mounted onto triaxial apparatus. It seems that extensive fragmentation did not affect compression behaviors in triaxial apparatus, because the extension cracks actually occurred in horizontal plane but shearing cracks due to undrained compression take place probably around an angle of $60^{\circ}$ to horizontal plane. The two kinds of cracks happen in fairly different planes. Moreover, the present experimental study was programmed excluding any kind of extension shear tests with the triaxial apparatus.

\section{Procedures of Triaxial Experiment}

After the specimens of lightweight treated samples were set on triaxial apparatus, back pressures (B.P.), equivalent to curing state, were applied on them. This state was kept for 10 minutes, expelling excess water or air out of the specimens. With the draining cock turned off, and additional isotropic cell pressures were applied on the specimens by $\Delta \sigma_{\mathrm{c}}=20,50,100,150$ and $300 \mathrm{kN} /$ $\mathrm{m}^{2}$, respectively. The second procedure was also kept for 10 minutes. Soon, undrained shear was carried out on specimens at an axial strain rate of $0.2 \% / \mathrm{min}$ with confining cell pressure constant.

Figure 8 shows initial volumetric strain before the specimens were subjected to undrained shearing. This value consists of contraction as the specimens were resumed to curing pressure (e.g., B.P. $=p_{\text {cure }}$ ) in drained state, in compensation to sample expansion due to curing pressure release, and the volumetric compression due to additional isotropic cell pressure $\Delta \sigma_{\mathrm{c}}$ in undrained state. Hereby, $\sigma_{\mathrm{c}}=$ B.P. $+\Delta \sigma_{\mathrm{c}}$ is called total cell pressure.

Figure 9 shows pore water pressure responding to the total cell pressure. The gradients in the figure are equivalent to pore pressure parameter $B_{\mathrm{i}}$, ranging between 0.17 to 0.83 . It appears that the air foam mixed samples exhibit lower pore pressure response when isotropic confining pressures exerted on them. As the authors' approximate estimate, the bulk compressibility $\left(K=\Delta \varepsilon_{\mathrm{v}} / \Delta p\right)$ varies about $K_{\mathrm{a}}=1 /\left(150-500 \mathrm{kN} / \mathrm{m}^{2}\right)$ for air foam, comparing about $K_{\mathrm{b}}=1 /\left(500-2500 \mathrm{kN} / \mathrm{m}^{2}\right)$ for EPS beads. That is, the air foam's compressibility is 3 to 5 times greater than that of EPS beads. This is the main reason why air foam mixed samples exhibit lower pore water pressure response, which is believed to be closely linked to the compressibility of mixed lightener. Usually, the 


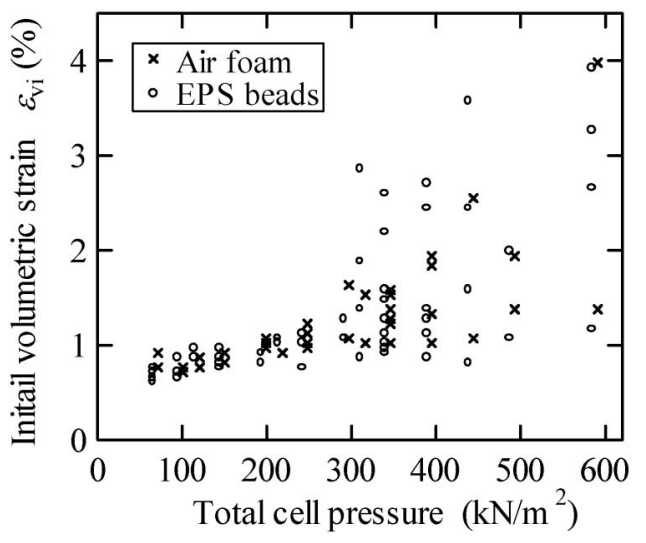

Fig. 8. Initial volumetric compression before undrained shearing

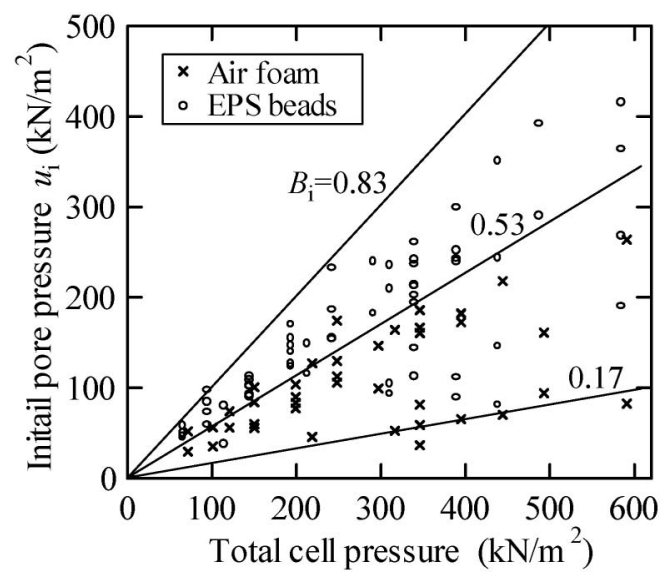

Fig. 9. Initial pore pressure response under back pressures and added cell pressures

greater the lightener's compressibility, the duller the pore water pressure response.

\section{Undrained Shearing Behavior}

Figures 10 and 11 show stress-strain curves for air foam mixed and EPS beads mixed cases respectively, when the specimens were subjected to undrained shearing, together with pore pressure $u$ and volumetric strain $\varepsilon_{\mathrm{v}}$ simultaneously occurring. It can be seen in each plot that stressstrain curves diverse as additional isotropic cell pressures become larger. This implies decrease in modulus of deformation $E$ with increase of cell pressure $\sigma_{\mathrm{c}}$.

Concerning compressive strength, $q_{\max }$, maximum of deviator stress $\left(\sigma_{\mathrm{a}}-\sigma_{\mathrm{c}}\right)$, it turned out as large as 1.5 to 2 times targeted unconfined compressive strength $q_{\mathrm{u}}$ in air foam mixed cases, although it was designed at $200 \mathrm{kN} / \mathrm{m}^{2}$ or $400 \mathrm{kN} / \mathrm{m}^{2}$, respectively. However, in EPS beads mixed cases, compressive strength $q_{\max }$, ranged among 0.75 to 1.2 times the corresponding targeted unconfined compressive strength. The correlation between compressive strength and curing pressure, added cell pressure will be examined later.

Apart from the shearing at the very beginning in some EPS beads mixed cases, it is also obvious that the volume of lightweight treated material tends to decrease its volume continuously throughout the whole shearing process. This fact shows that the lightweight soil is basically shear-shrinking geomaterial which exhibits negative dilatancy behavior.

Figures 12 to 15 show effective stress paths during undrained shearing, together with compression curves evaluated in terms of air foam or EPS beads void ratio. For the air foam mixed cases as shown in Figs. 12 and 13, the paths generally set off at a slope of 3:1. Successively, they vary with degree of cell pressures. When cell pressures are fairly small as compared with intrinsic compressive strength $q_{\text {max }}$, they keep along straight lines of 3:1 because pore pressure remains nearly unchanged. Generally speaking, over consolidated clays show small absolute values of the pore water pressure coefficients $A$ when they are subjected to undrained shearing. The lightweight soils treated with cement were hardened and could be regarded as a quasi over consolidated clay. So at the beginning of shearing the changes in pore water pressure maybe had been very small. The small changes further waned due to

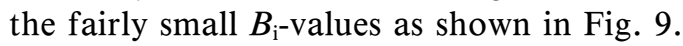

With cell pressures increasing, the paths tend to bend somewhere, pass by peak of deviator stress and residually converge towards critical area. It seems that there exist peak envelopes of deviator stress, suggesting that compressive strength $q_{\text {max }}$ increases with mean effective stress for air foam mixed samples. Similarly, EPS beads mixed samples trace effective stress paths as shown in Figs. 14 and 15. Effect stress paths do not apparently set off at a slope of $3: 1$ because pore pressure responds more than those in air mixed samples. It is difficult to infer the similar peak envelopes. Nevertheless, in both mixed cases, a common tendency of effective stress paths ultimately approaching the critical state line, which is identified as $M=$ 1.8 for Kawasaki clay was recognized.

Ascribing to large compressibility of lightener, the lightened soil exhibits considerable volumetric compression when subjected to undrained shearing. Here, void ratio $e$ for the lightened soil is thought as a sum of pore water's portion $e_{\mathrm{w}}$ and lightener's portion $e_{\mathrm{a}}$ for air foam or $e_{\mathrm{b}}$ for EPS beads. That is, $e=e_{\mathrm{w}}+e_{\mathrm{a}}\left(\right.$ or $\left.e_{\mathrm{b}}\right)$. Under the assumption of un-compressibility for soil particles and water during the whole process, volumetric change attributes to lightener alone. Figures 12 to 15 also present compressive behaviors in compression plan, where vertical axis is given in void ratio of lightener $e_{\mathrm{a}}$, or $e_{\mathrm{b}}$. Before set to pressured curing, the lightweight treated soils were designed with initial void ratio $e_{\mathrm{a} 0}=0.52$ for air foam mixed samples and $e_{\mathrm{b} 0}=0.59$ for those of EPS beads mixed samples. Due to series of procedures; pressured curing, pressure release, sample trimming, curing pressure resuming and adding cell pressure, actual void ratio of lightener varies from 0.12 to 0.52 , definitely depends on curing and added cell pressures. Most likely, long periods of pressured curing has induced pore water invasions into air bubbles or EPS beads to a slight extent. Also, there maybe a little water absorption or drainage incident to the specimen preparing procedures. Such variances in 

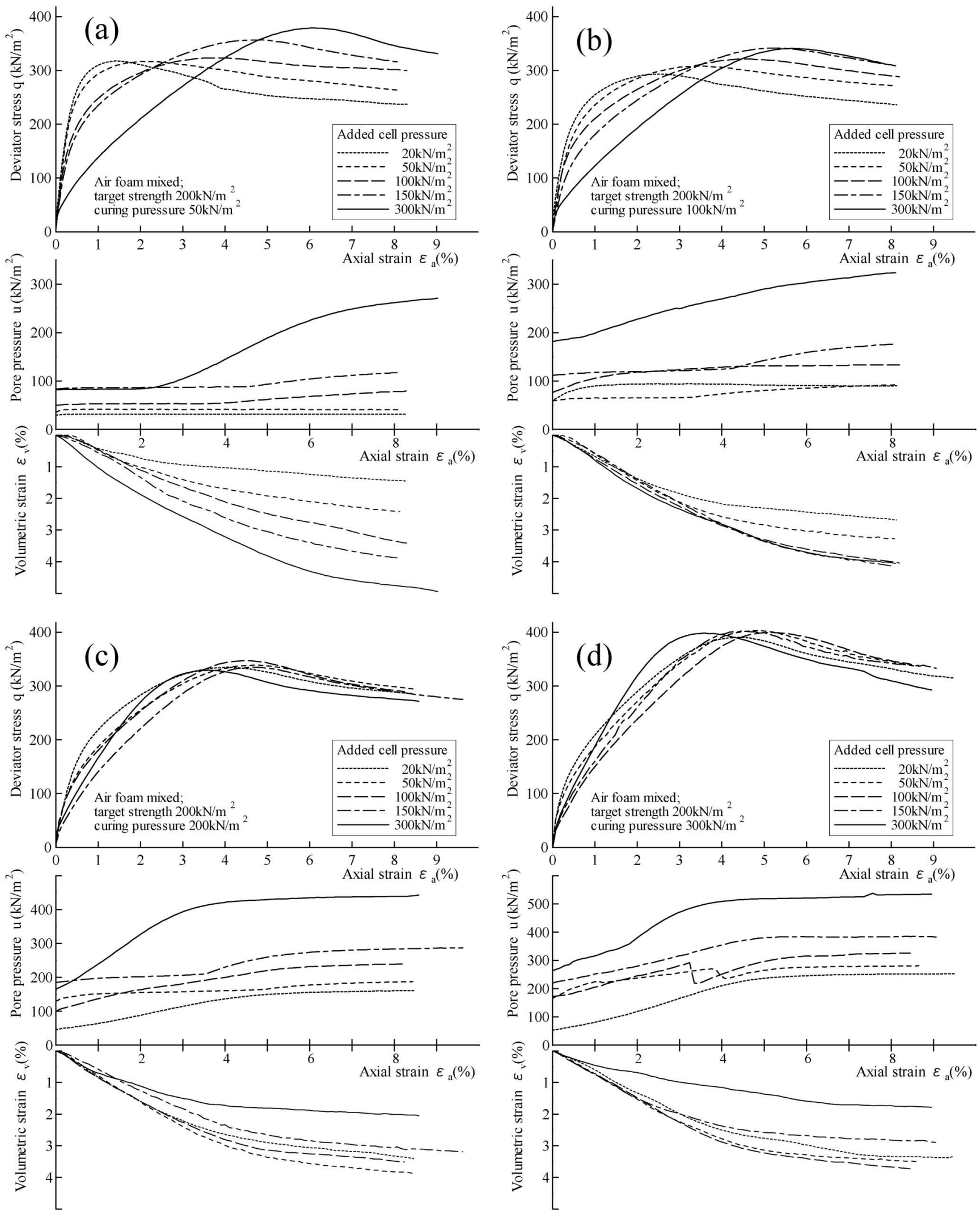

Fig. 10(a) $\sim$ (d). Undrained shearing behaviors of lightweight treated soil (air foam mixed, target $q_{\mathrm{u}}=200 \mathrm{kN} / \mathrm{m}^{2}$ )

pore water are quite small as considering void ratio $e_{\mathrm{w}}$, their effects are not taken into account here.

From the compression paths shown in Figs. 12 to 15, it is clear that void ratio of lightener keeps decreasing dur- ing the whole undrained shearing process. In these figures, arrows indicate the direction in which compression paths traced. At the end of shearing tests, void ratio of lightener changes with various factors, including total 

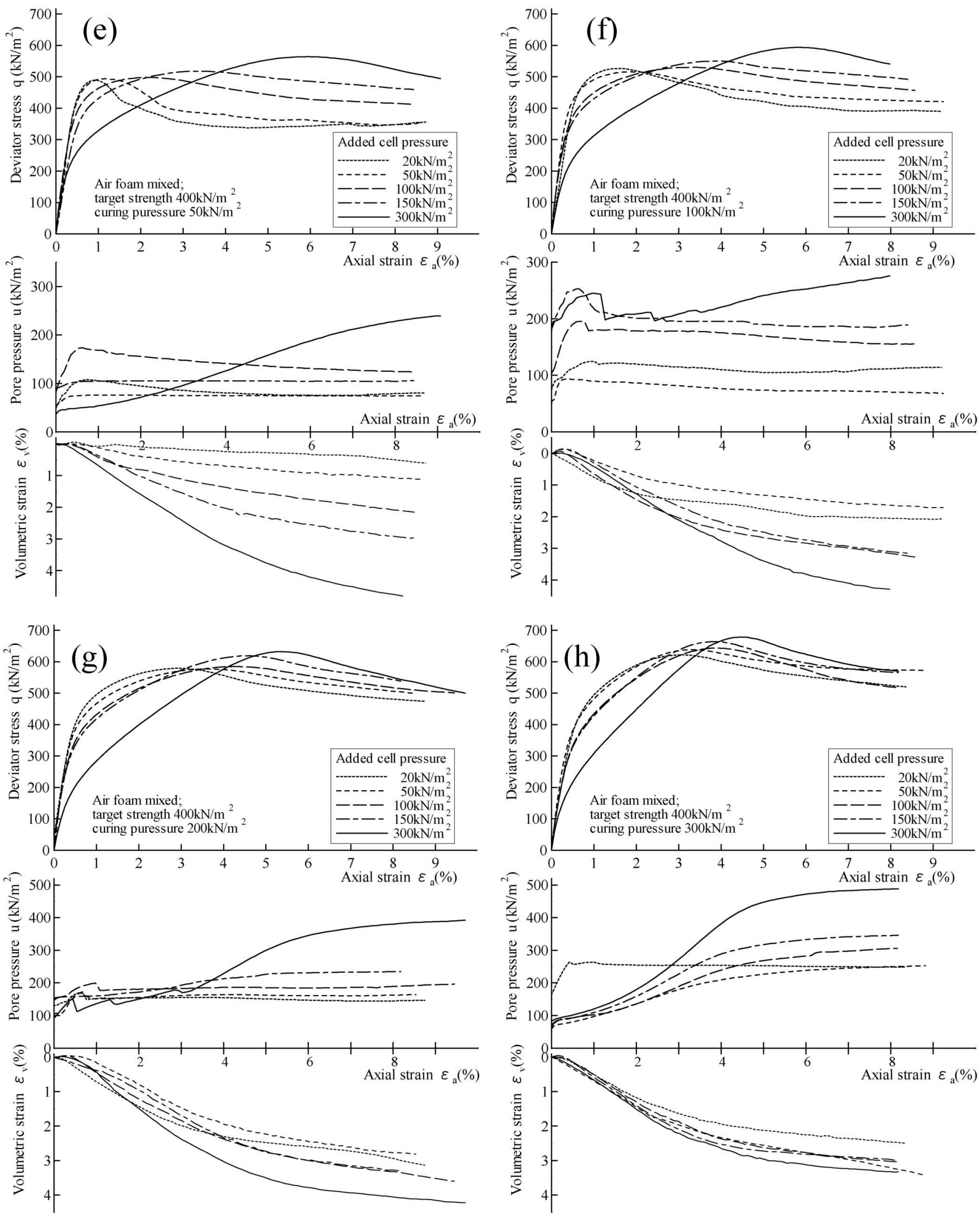

Fig. 10(e) $\sim(\mathrm{h})$. Undrained shearing behaviors of lightweight treated soil (air foam mixed, target $q_{\mathrm{u}}=400 \mathrm{kN} / \mathrm{m}^{2}$ )

confining cell pressure, lightener type and samples' target strength. If the cell pressure is large enough in comparison with actual compressive strength, then the final void ratio of lightener tends to converge near zero.

\section{ASPECTS BASED ON THE CONDUCTED TESTS}

Unit Weight

Figure 16 shows unit weight of samples immediately 

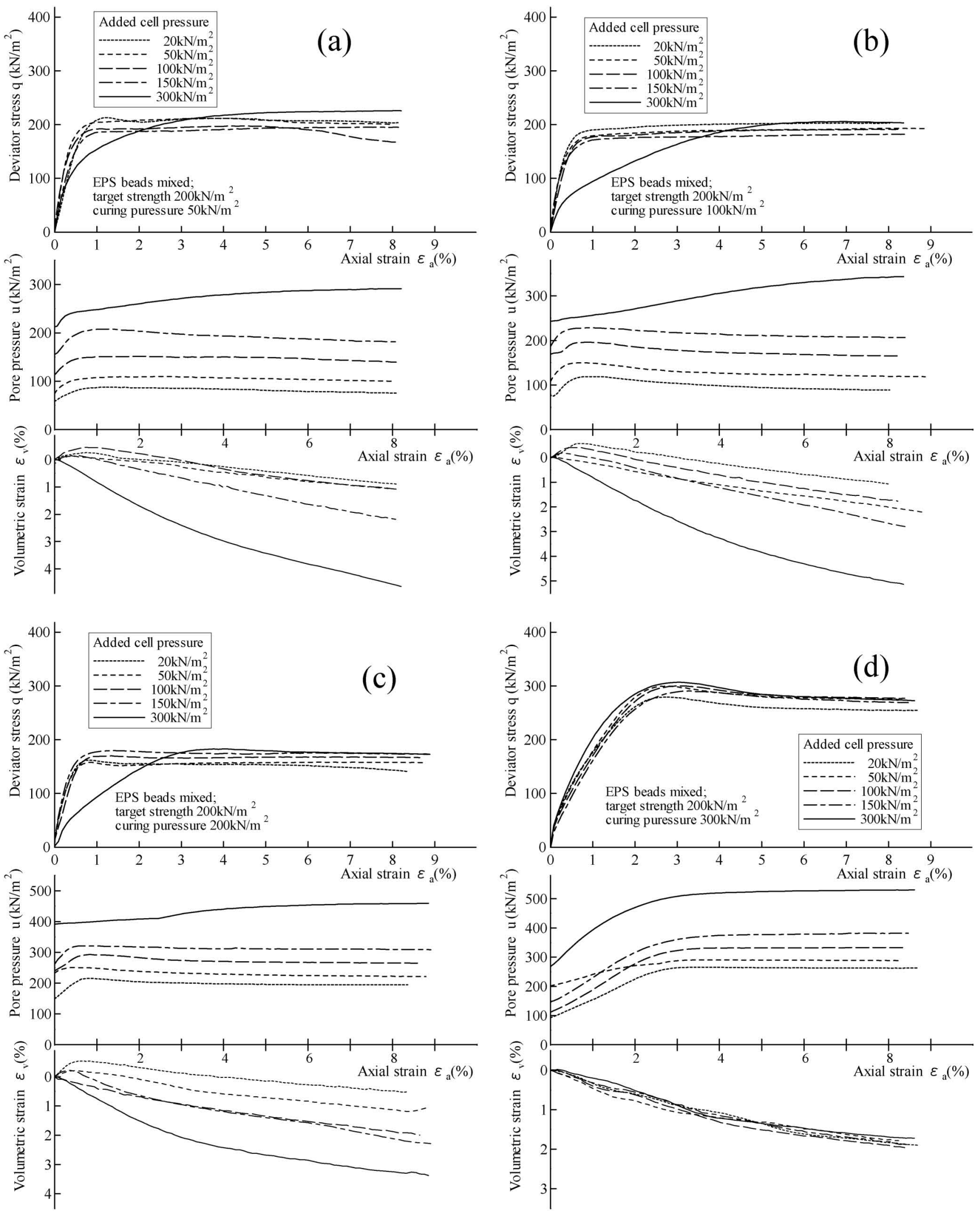

Fig. 11(a) $\sim$ (d). Undrained shearing behaviors of lightweight treated soil (EPS beads mixed, target $q_{\mathrm{u}}=200 \mathrm{kN} / \mathrm{m}^{2}$ )

before being set onto triaxial apparatus. Though it was designed at $12 \mathrm{kN} / \mathrm{m}^{3}$, unit weight ranged from 11.8 $\mathrm{kN} / \mathrm{m}^{3}$ to $12.8 \mathrm{kN} / \mathrm{m}^{3}$, with an apparent tendency to increase with increasing curing pressure. It can be said from the present study that every increment of $1 \mathrm{kN} / \mathrm{m}^{2}$ in water pressure brings about an increment of $2 \mathrm{~N} / \mathrm{m}^{3}$ to 3 $\mathrm{N} / \mathrm{m}^{3}$ in unit weight. This result is essentially in agreement with what is predicted by Boyle's Law. 

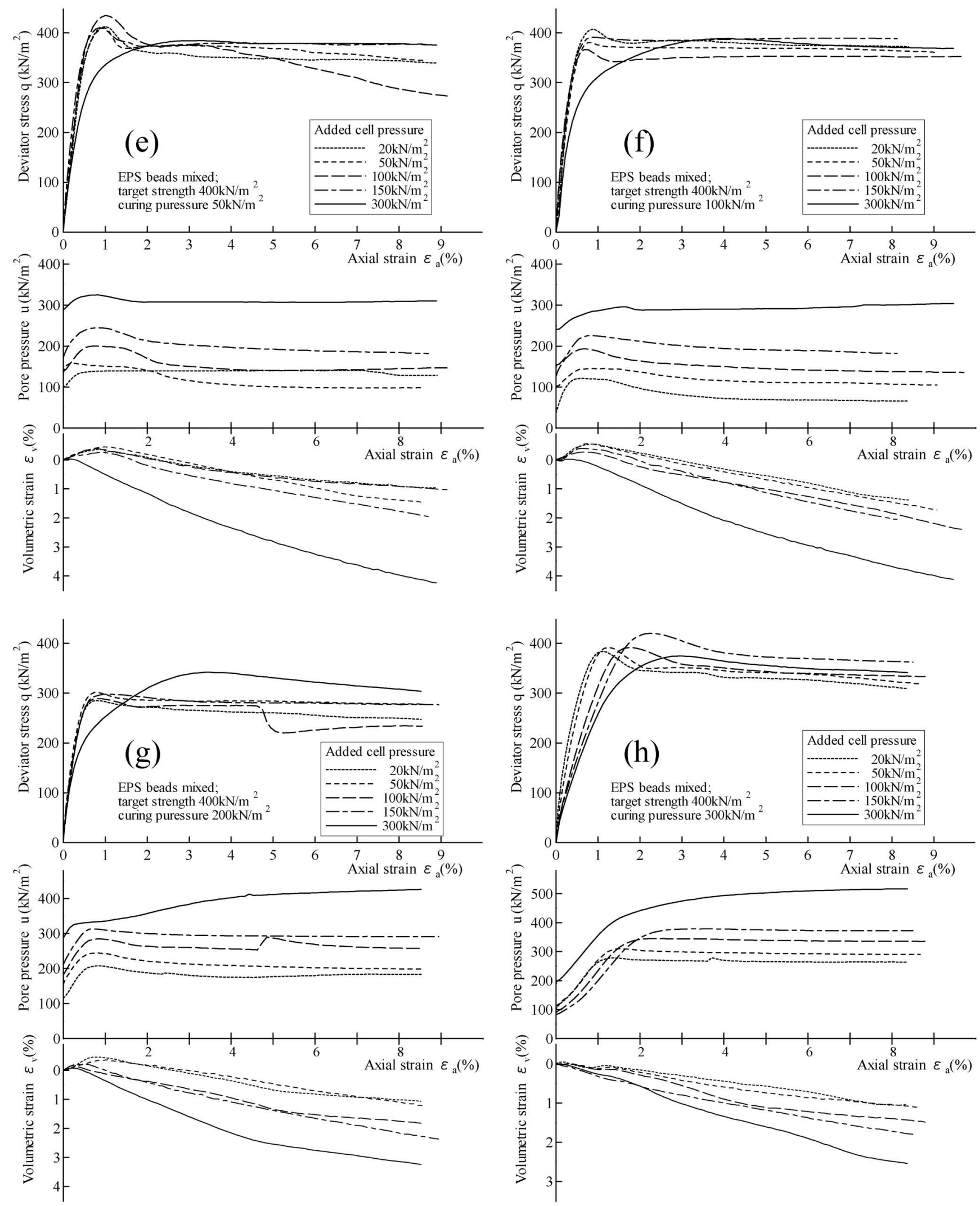

Fig.11(e) $\sim$ (h). Undrained shearing behaviors of lightweight treated soil (EPS beads mixed, target $q_{\mathrm{u}}=400 \mathrm{kN} / \mathrm{m}^{2}$ )

\section{Compressive Strength}

Compressive strength is defined as the maximum value of deviator stress, $q_{\max }=\max \left(\sigma_{\mathrm{a}}-\sigma_{\mathrm{c}}\right)$. This strength becomes equivalent to unconfined compressive strength if cell pressure is totally eliminated. Figure 17 displays the effect of pressured curing for air foam mixed samples. It reveals that higher curing pressure enhances compressive strength after they are cured. This strength rising feather 

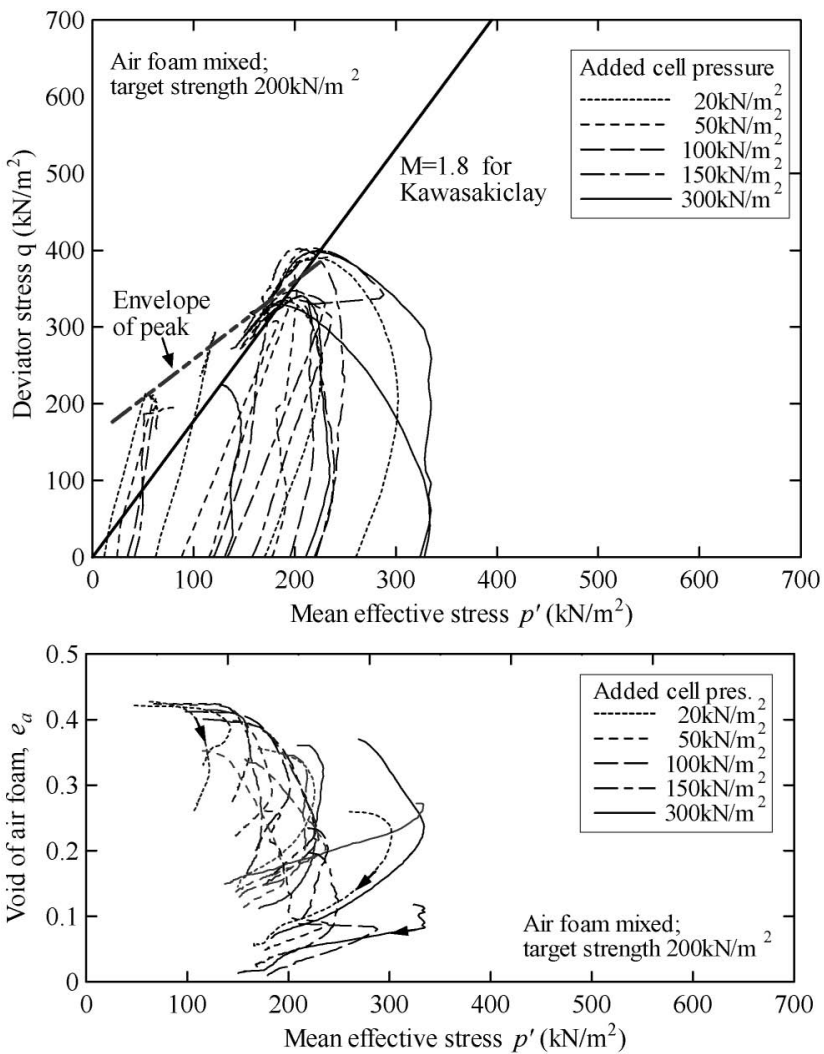

Fig. 12. Effective stress path and compression path (air foam mixed, target $q_{\mathrm{u}}=200 \mathrm{kN} / \mathrm{m}^{2}$ )
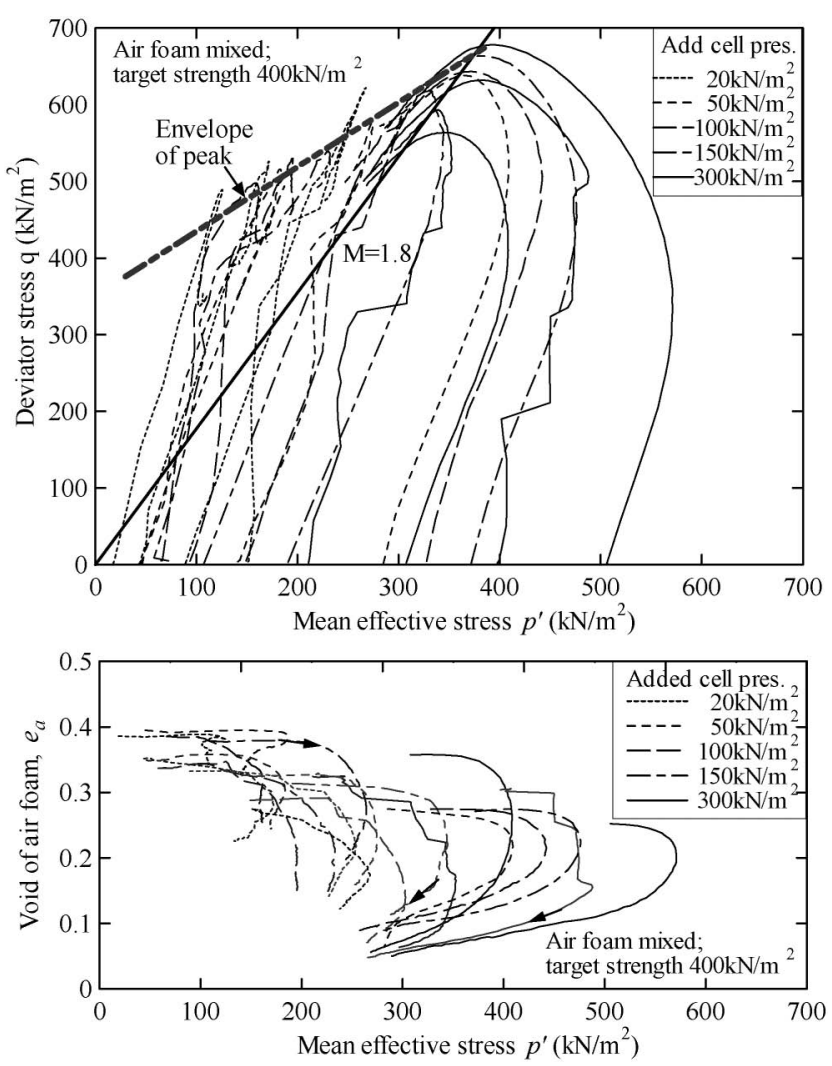

Fig. 13. Effective stress path and compression path (air foam mixed, target $q_{\mathrm{u}}=400 \mathrm{kN} / \mathrm{m}^{2}$ )
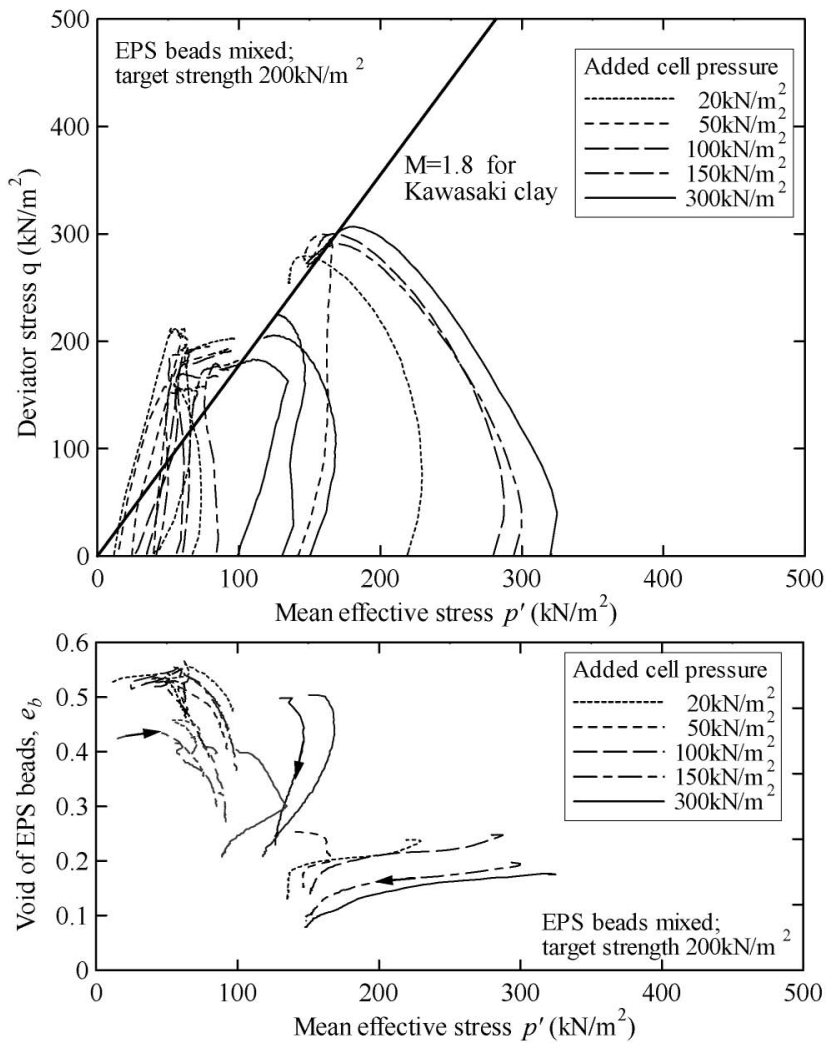

Fig. 14. Effective stress path and compression path (EPS beads mixed, target $q_{\mathrm{u}}=200 \mathrm{kN} / \mathrm{m}^{2}$ )
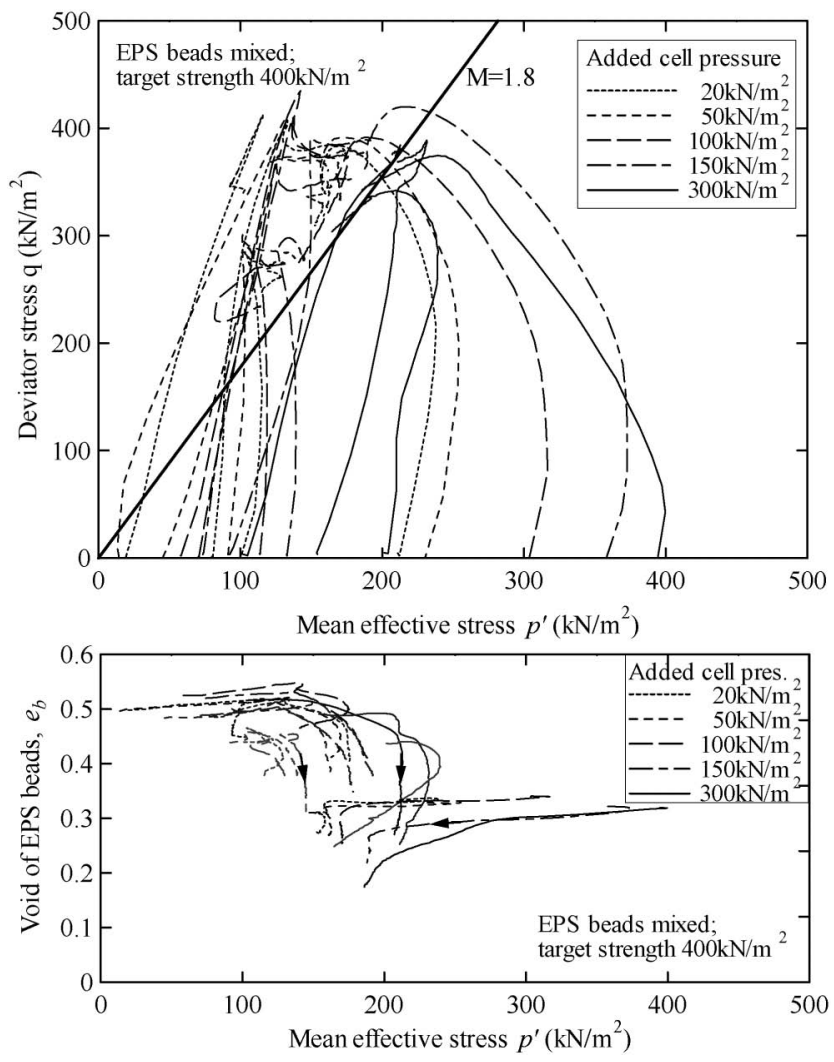

Fig. 15. Effective stress path and compression path (EPS beads mixed, target $q_{\mathrm{u}}=400 \mathrm{kN} / \mathrm{m}^{2}$ ) 


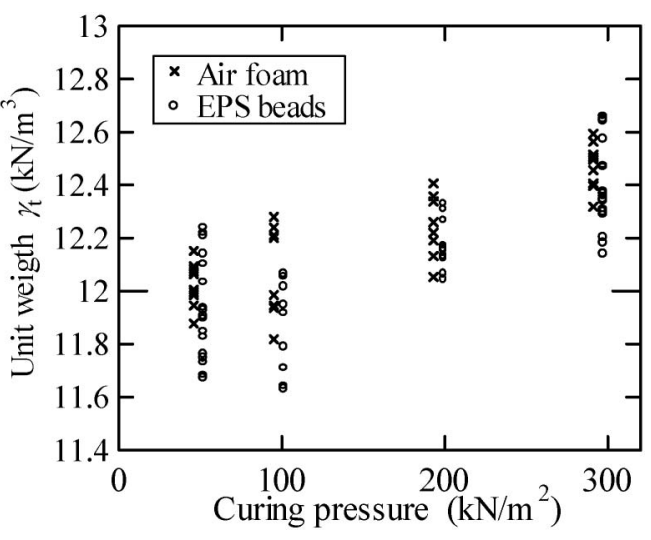

Fig. 16. Increment in unit weight due to pressure curing

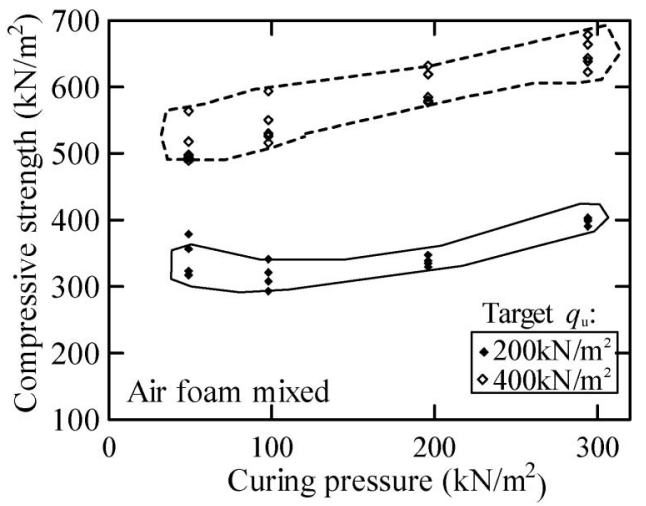

Fig. 17. Effect of pressured curing on compressive strength of air foam mixed samples

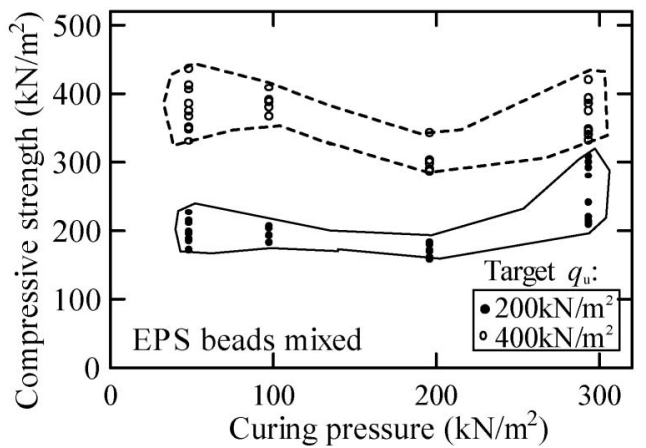

Fig. 18. Effect of pressured curing on compressive strength of EPS beads mixed samples

is associated with increase in unit weight. In the case of EPS beads mixed samples as shown in Fig. 18, however, there seems a slight decrease in compressive strength with increasing curing pressure. In particular, it exhibits a minimum strength at curing pressure of $200 \mathrm{kN} / \mathrm{m}^{2}$. Such a feather is interpreted due to rheological nature of EPS beads. Figure 19 presents deformation behavior of EPS beads compressed under isotropic water pressures. It is testified that EPS beads yields around $200 \mathrm{kN} / \mathrm{m}^{2}$. For EPS beads under a certain water pressure, it shows both

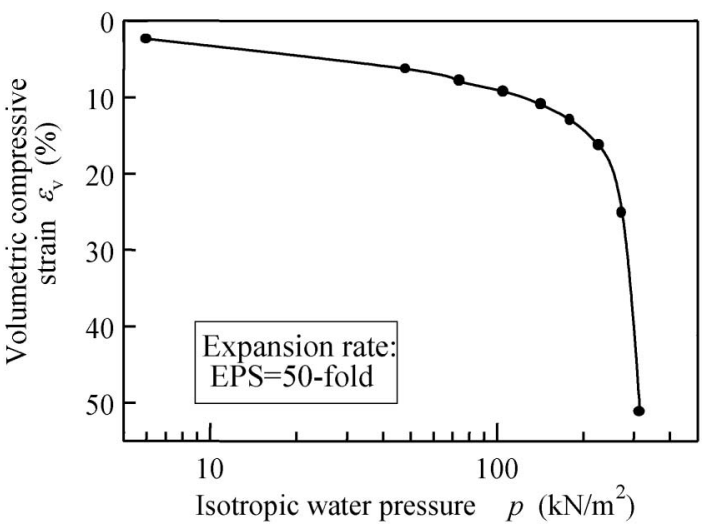

Fig. 19. Compressibility of EPS beads under water pressure

instant and creep compressions. In fact, the compression curve of Fig. 19 was obtained within 1 minute after water pressure was applied. It seemed that the reduction of the bulk of EPS beads would continue for a long time at constant pressures, and the rate of volume reduction was prominent especially when the water pressure is close to the yield pressure. Although the creep behavior has not investigated in detail, the rate of creep compression, alike to the coefficient of secondary consolidation, could be obtained by $C_{\mathrm{a}}=\Delta \varepsilon_{\mathrm{v}} /(\log (t+\Delta t)-\log (t))$. Here, $\Delta \varepsilon_{\mathrm{v}}$ is the creep compression occurring within a time span of $t$ to $t+\Delta t$. On the other hand, suppose neither volumetric strain nor shearing strain is exerted on the samples during the curing period, almost all the cement treated soils continue to harden. Similarly, the rate of cement hardening could be obtained by $C_{\mathrm{qu}}=\Delta q_{\mathrm{u}} /(\log (t+\Delta t)-\log (t))$ if compressive strength gain $\Delta q_{\mathrm{u}}$ occurred within the same time span. However, EPS beads does exhibit creep compression which is thought to deteriorate the compression strength $q_{\mathrm{u}}$, because it will damage the hardened frameworks generated among soil particles.

If the creep compression (or its effect on strength) is small enough to ignore, or it finishes in a relative short time (e.g., 1 or 2 hours before cement hardening starts), this effect could be overlooked. Yet, in cases that the phenomenon continues for several days to several weeks with considerable $\Delta \varepsilon_{v}$, the creep compression may inhibit profoundly the strength development of cement hardening.

Figure 20 illustrates the relationship between compressive strength and unit weight. Significant increases in compressive strength accompany increases in unit weight obviously for air foam mixed samples. Though the same tendency was found in EPS beads mixed cases, the increments were much smaller.

\section{Characteristics at Large Deformation}

Concerning pore water pressure response at large deformation, it is supposed to evaluate coefficients $B_{\mathrm{f}}$ and $A_{\mathrm{f}}$ with the relation of $u_{\mathrm{f}}=B_{\mathrm{f}}\left(\sigma_{\mathrm{c}}+A_{\mathrm{f}} q_{\mathrm{f}}\right)$, in which $u_{\mathrm{f}}$ and $q_{\mathrm{f}}$ are pore pressure and deviator stress eventually measured at axial strains greater than $8 \%$. Precisely, two 

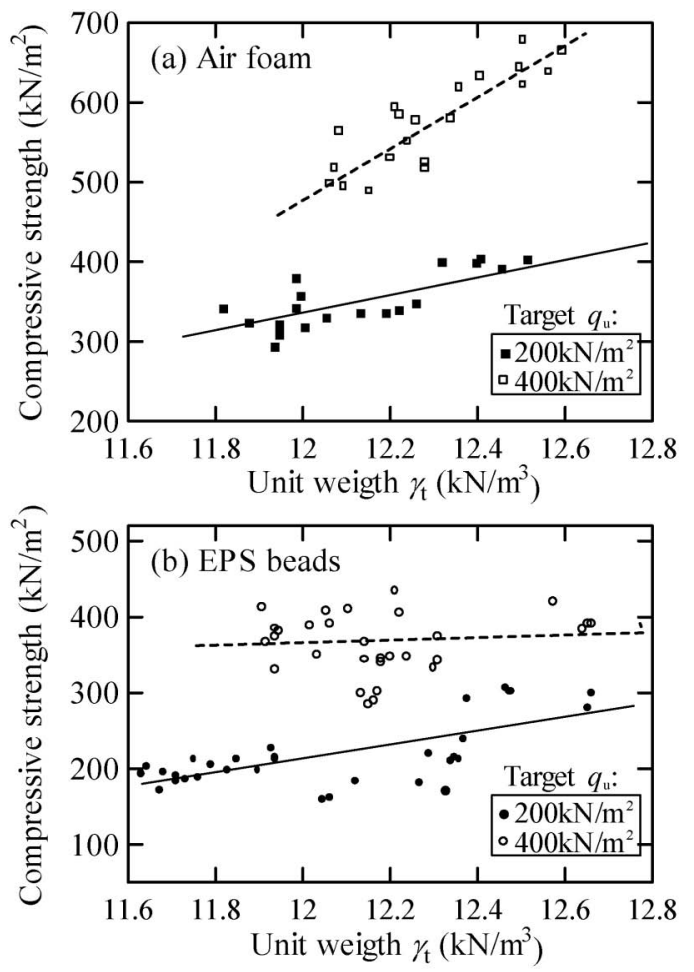

Fig. 20. Correlation between compressive strength and unit weight

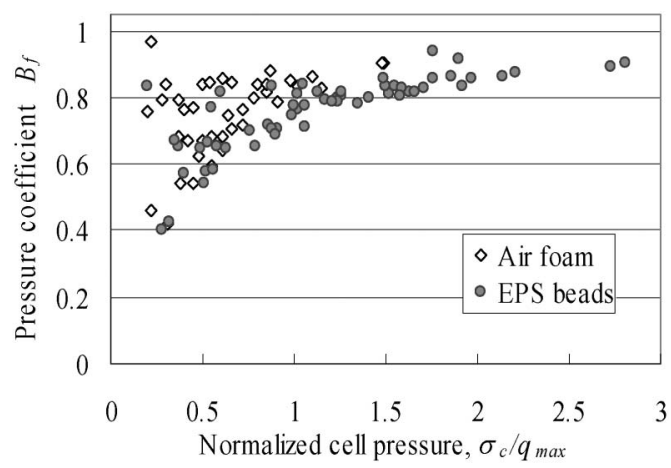

Fig. 21. Pore pressure coefficient $B_{\mathrm{f}}$ at ultimate axial strain

unknown coefficients $B_{\mathrm{f}}$ and $A_{\mathrm{f}}$ cannot be determined with only one relation. Here, we temporarily presume $A_{\mathrm{f}}$ $=0$ and roughly estimate $B_{\mathrm{f}}$-value with $B_{\mathrm{f}}=u_{\mathrm{f}} / \sigma_{\mathrm{c}}$.

Figure 21 shows pore pressure coefficient $B_{\mathrm{f}}$, which is determined at eventual axial strains greater than $8 \%$. The horizontal axis indicates the total cell pressure normalized by actual compressive strength $q_{\max }$. Sheared under undrained condition, pore pressure coefficient $B$ increased from very low initial values as shown in Fig. 9 up to about 0.8 . For air mixed cases, it seems that $B_{\mathrm{f}}$ is 0.8 irrelevant to relative cell pressure $\left(\sigma_{\mathrm{c}} / q_{\max }\right)$, approximately. On the other hand, there is a tendency that $B_{\mathrm{f}}$ increases with relative cell pressure $\left(\sigma_{\mathrm{c}} / q_{\max }\right)$ for EPS beads mixed cases.

Figure 22 shows another pore pressure coefficient $A_{\mathrm{f}}$, as given by $\left(u_{\mathrm{f}} / B_{\mathrm{f}}-\sigma_{\mathrm{c}}\right) / q_{\mathrm{f}}$, where $B_{\mathrm{f}}$ is roughly regarded as a constant value of 0.8 . Although the $A_{\mathrm{f}}$ value given in Fig.

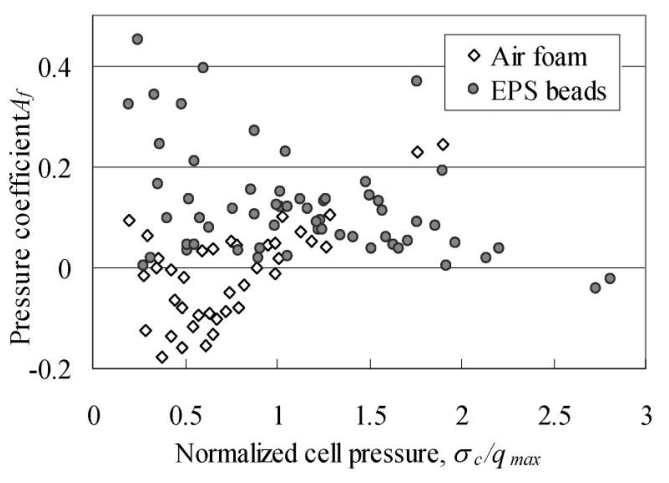

Fig. 22. Pore pressure coefficient $A_{\mathrm{f}}$ at ultimate axial strain
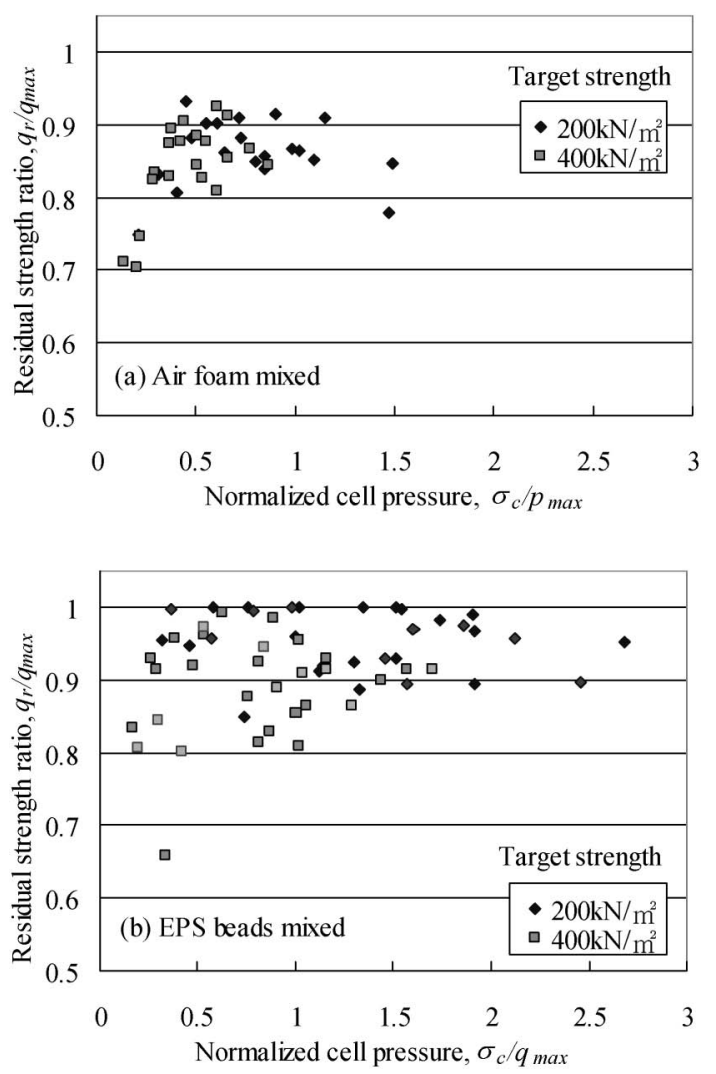

Fig. 23. Residual compressive strength $q_{\mathrm{r}}$ at ultimate axial strain

22 seems suspicious due to the inexactness of $B_{\mathrm{f}}$ value, the result is still useful for an overall evaluation of its tendency. It can be seen that $A_{\mathrm{f}}$ value scatters between -0.2 to 0.15 for air foam mixed material, but varies between 0 to 0.4 and gradually converges to 0 with increasing $\left(\sigma_{\mathrm{c}}\right)$ $\left.q_{\text {max }}\right)$ for EPS beads mixed material.

Figure 23 shows residual strength ratio $q_{\mathrm{r}} / q_{\text {max }}$ plotted against relative cell pressure $\left(\sigma_{\mathrm{c}} / q_{\text {max }}\right)$. Here, residual strength $q_{\mathrm{r}}$ was tentatively determined also at eventual axial strains. For air foam mixed samples, it was found that about $80 \%$ to $90 \%$ of compressive strength remains by the eventual strains. Furthermore, $80 \%$ to $100 \%$ of compressive strength remains for EPS beads mixed samples. This result indicates that the present cement treated light- 

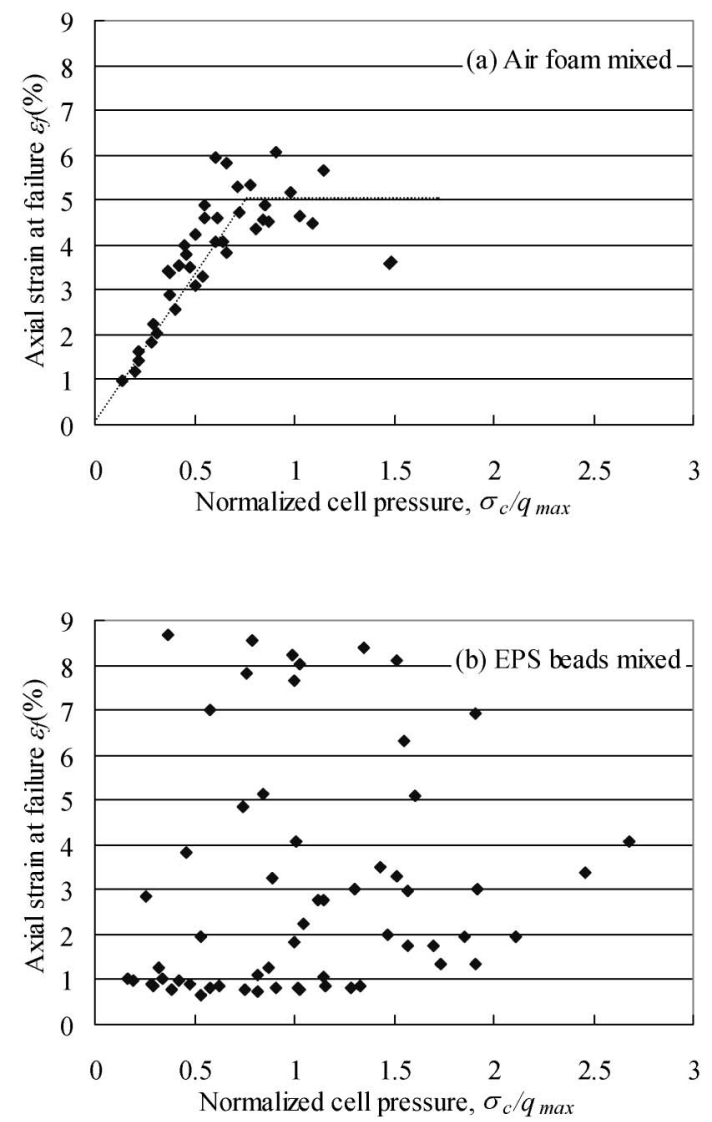

Fig. 24. Axial strain at failure

weight soils are not vulnerable materials when they are deployed under confined conditions.

\section{Deformation Properties}

Figure 24 shows axial strains at failure (maximum deviator stress), $\varepsilon_{\mathrm{f}}$ plotted against relative cell pressure $\left(\sigma_{\mathrm{c}} /\right.$ $\left.q_{\text {max }}\right)$. In the air foam mixed cases, failure strain increases with increasing cell pressure, suggesting that lower compressive strength and higher confining pressure will delay the failing juncture. As the relative cell pressure exceeds 0.75 , it looks like that failure strain remains roughly constant of about $5 \%$. In contrary, there was no such apparent trend between failure strain and cell pressure in EPS beads mixed cases. As seen in the figure, failure strains are plotted sporadically in a wide range from $0.7 \%$ to $8.7 \%$.

Deformation modulus $E_{50}$ here is defined as scant gradient at the point of half strength on the deviator stress-axial strain curve. Figure 25 shows deformation modulus plotted against the relative cell pressure. Despite of the few differences in scatter degree, deformation modulus steadily decreases in both mixed cases as cell pressure is increased. Figure 26 presents the correlation between the modulus and compressive strength. It can be seen that they are correlated with $E_{50}=(40-220) q_{\max }$ for air foam mixed samples and $E_{50}=(50-270) q_{\max }$ for those of EPS beads mixed. Certainly, smaller coefficients correspond to larger cell pressures.
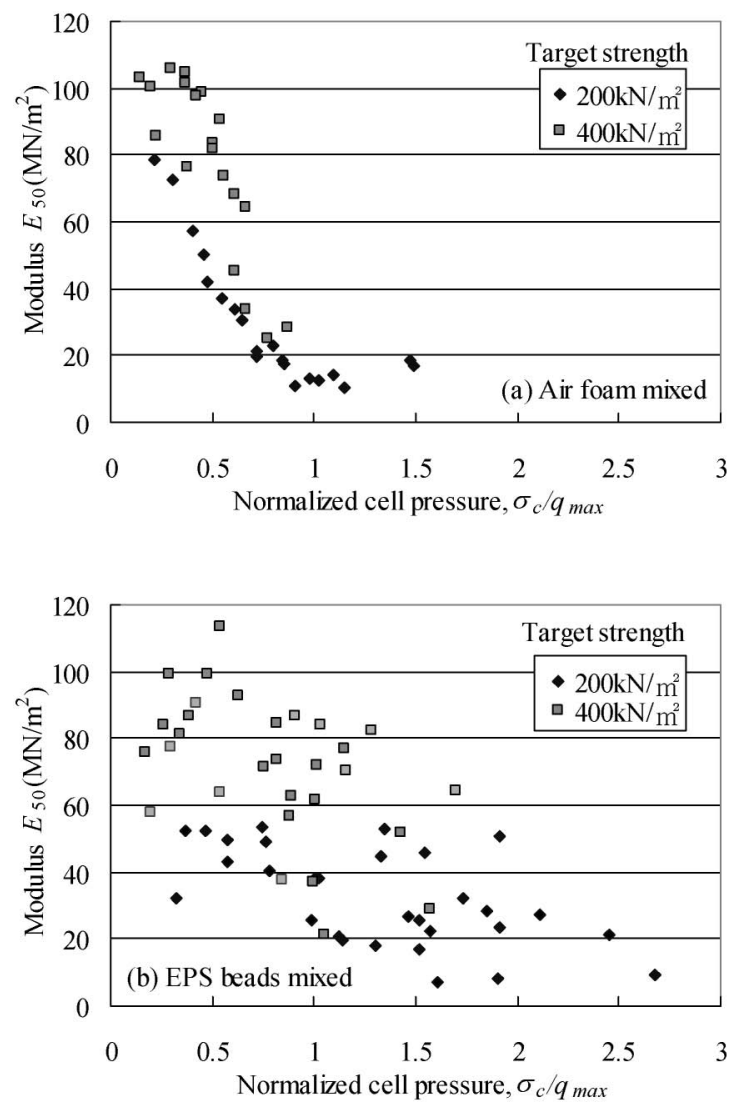

Fig. 25. Modulus varying with normalized cell pressure
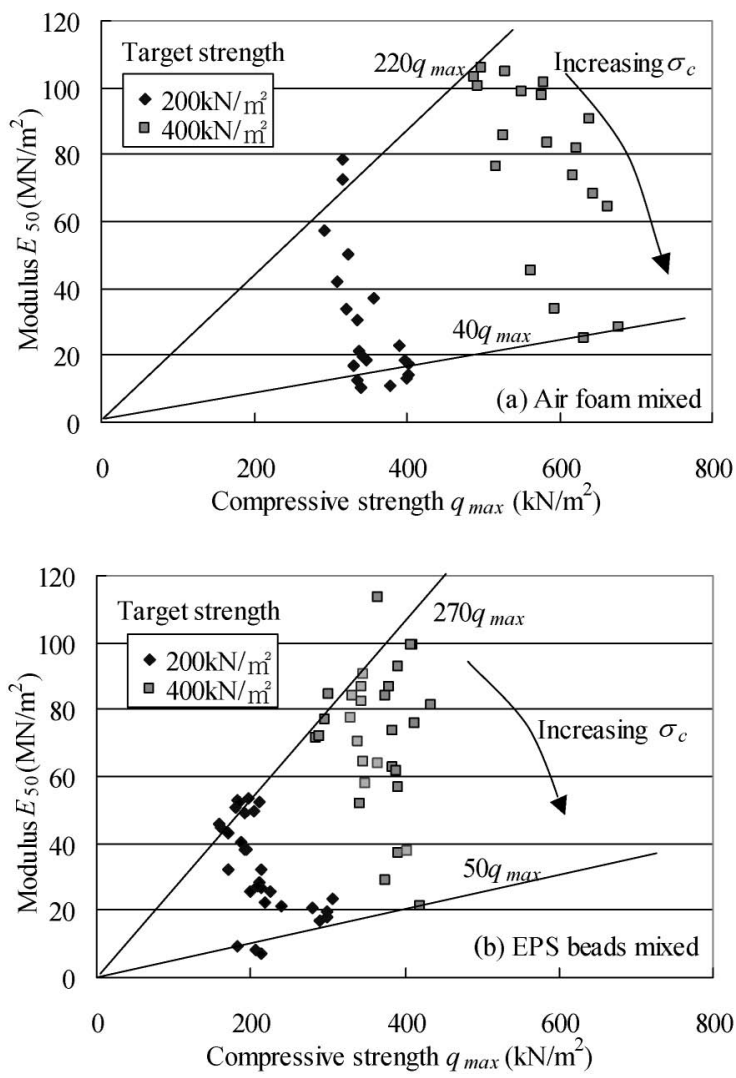

Fig. 26. Correlations between modulus $E_{50}$ and compressive strength $q_{\max }$ 

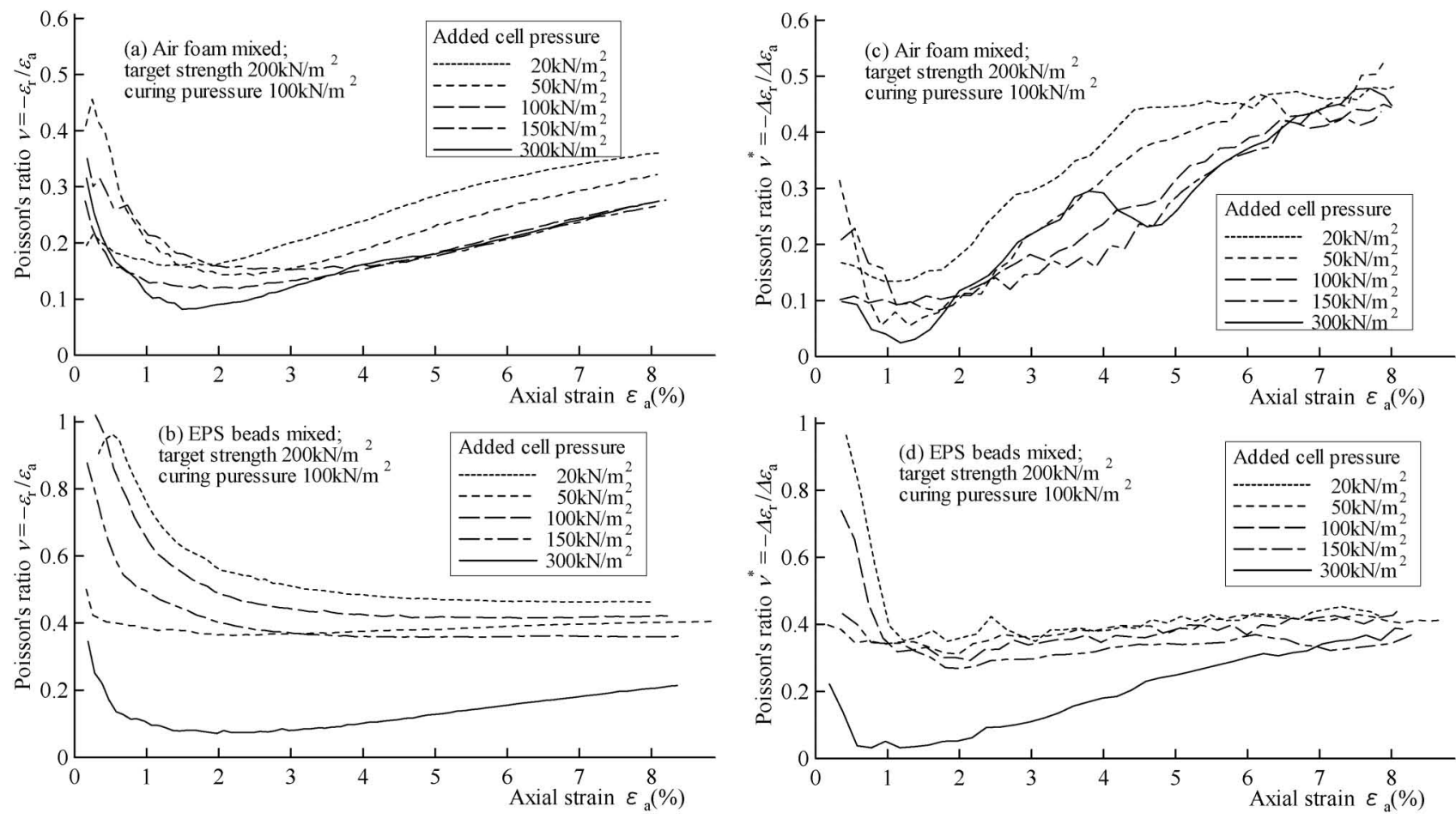

Fig. 27. Variances of Poisson's ratio during undrained shearing: (a) $\sim$ (b) defined with $v=-\varepsilon_{\mathrm{r}} / \varepsilon_{\mathrm{a}}$ and (c) $\sim(\mathrm{d})$ defined with $v^{*}=-\Delta \varepsilon_{\mathrm{r}} / \Delta \varepsilon_{\mathrm{a}}$

Poisson's ratio is usually described as the ratio of lateral strain to axial strain by $v=-\varepsilon_{\mathrm{r}} / \varepsilon_{\mathrm{a}}$ in triaxial experiments. Yet, it is sometimes more practical to define it as the ratio of increment of lateral strain to increment of axial strain by $v^{*}=-\Delta \varepsilon_{\mathrm{r}} / \Delta \varepsilon_{\mathrm{a}}$. Figure 27 presents typical results analyzed on the basis of Figs. 12 and 14. It is evident that Poisson's ratio is far from a constant parameter during the whole shearing process. At the beginning, it decreases rapidly until axial strain reaches $1 \%$ to $2 \%$, then turns to increase towards ultimate values about 0.4 . Though mere is difference caused by definition method, Poisson's ratio is influenced by lightener's type definitely. It seems that EPS beads mixed material exhibits Poisson's ratio much larger than that of air foam materials.

\section{$K_{0}$-CONSOILDATION TEST}

$K_{0}$-consolidation was carried out to comprehend coefficient of pressure ratio at rest $K_{0}$, as well as consolidation yield pressure $p_{\mathrm{c}}$ for lightweight treated soils. Suggest the artificial geomaterial is utilized as a back fill material for revetment structures; the $K_{0}$ value is necessary to estimate earth pressure acting on the structure wall. Pradhan et al. (1994) had carried out $K_{0}$-consolidation on lightweight soil, of which ingredient soil was sand and lightener was EPS beads. Figure 28 shows effective stress ratio $K=s_{\mathrm{r}}^{\prime} / \sigma_{\mathrm{a}}^{\prime}$ against axial effective stress. It was found that effective stress ratio $K$ shows a minimum value of about 0.2 . This is quite a small value as compared with usual soils, with $K_{0}$ value ranging within $0.4 \sim 0.5$.

In the present study, the authors harnessed the same modified triaxial apparatus to perform $K_{0}$-consolidation

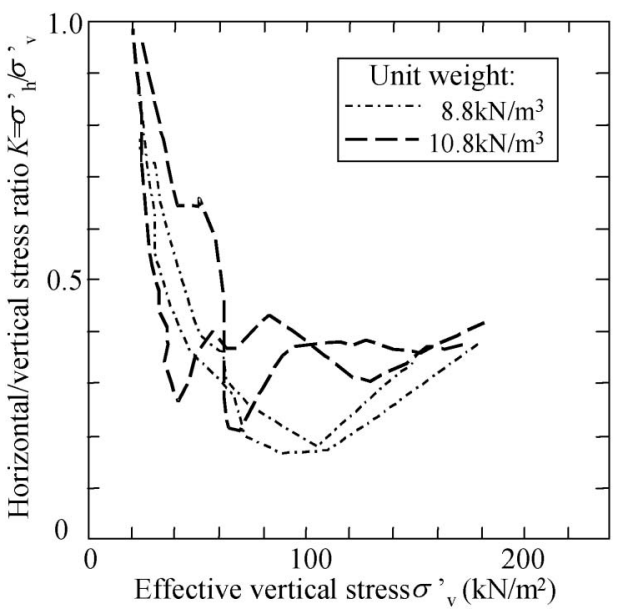

Fig. 28. Horizontal/vertical stress ratio obtained from lightweight treated sandy soil (Pradhan et al., 1994)

experiments on lightweight treated materials. Something different from underwater pressure specialized in UU tests previously stated, $K_{0}$-consolidation were conducted to cover the general situations where lightweight treated soils are utilized near or above the water table. Samples were cured at the pressure of atmosphere under humid circumstance for 28 days. At the beginning, the samples were pre-consolidated under a small isotropic pressure of $20 \mathrm{kN} / \mathrm{m}^{2}$ so as to get rid of excessive water or air. In $K_{0^{-}}$ consolidation process, axial stress was increased at a constant rate $\Delta \sigma_{\mathrm{a}} / \Delta t=65 \mathrm{kN} / \mathrm{m}^{2} /$ hour until $1000 \mathrm{kN} / \mathrm{m}^{2}$. On the other hand, lateral stress was increased in such a manner that no expanding lateral strain was allowed to 


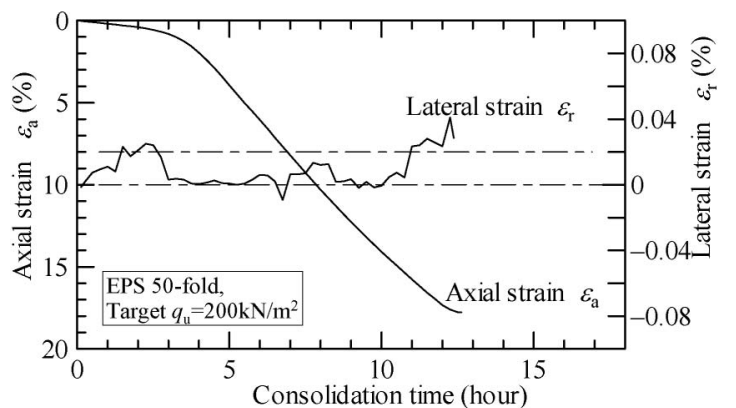

Fig. 29. Axial and lateral stains during $K_{0}$ controlled consolidation

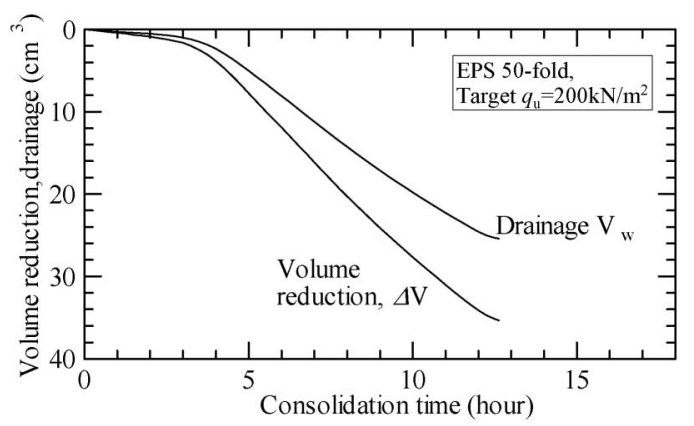

Fig. 30. Volume reduction and water drainage out of specimen

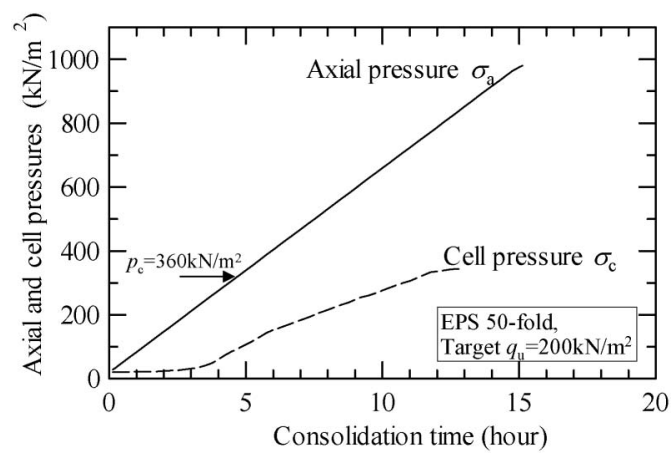

Fig. 31. Constantly increased axial pressure and adjusted cell pressure

take place. When axial load limit $\left(\max .1000 \mathrm{kN} / \mathrm{m}^{2}\right)$ or strain limit (max. $15 \%$ ) was reached, $K_{0}$ controlling was terminated. Figure 29 illustrates typical axial and lateral strains during the $K_{0}$-controlled process. It can be seen that lateral strain was kept not to exceed $\varepsilon_{\mathrm{r}}=0.02 \%$, while merely expanding lateral strain was allowed. Figure 30 indicates water drainage and volume reduction of specimen. It is clear that volume reduction proves greater than water drainage perpetually in a certain proportion, reflecting the compressibility of mixed lightener.

Figure 31 presents axial and cell pressures as $K_{0}$-consolidation progresses. It was found that no adjustment of cell pressure was performed until axial pressure approached to consolidation yield pressure $\left(p_{\mathrm{c}}=360 \mathrm{kN} /\right.$ $\left.\mathrm{m}^{2}\right)$. Figure 32 shows compression characteristic of lightweight treated soil by $K_{0}$-consolidation, a quasi onedimensional condition. It is important to realize that

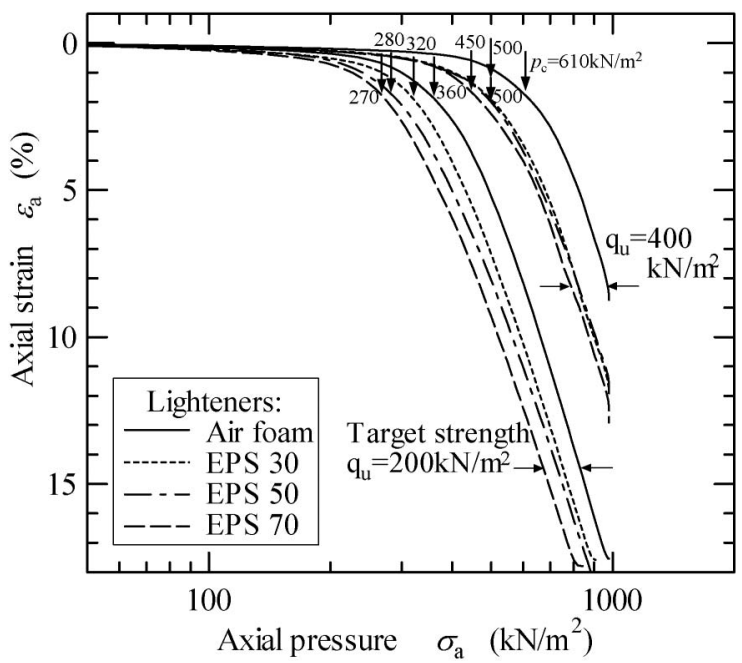

Fig. 32. Compression curves of $\varepsilon_{\mathrm{a}} \sim \log \sigma_{\mathrm{a}}$ relation
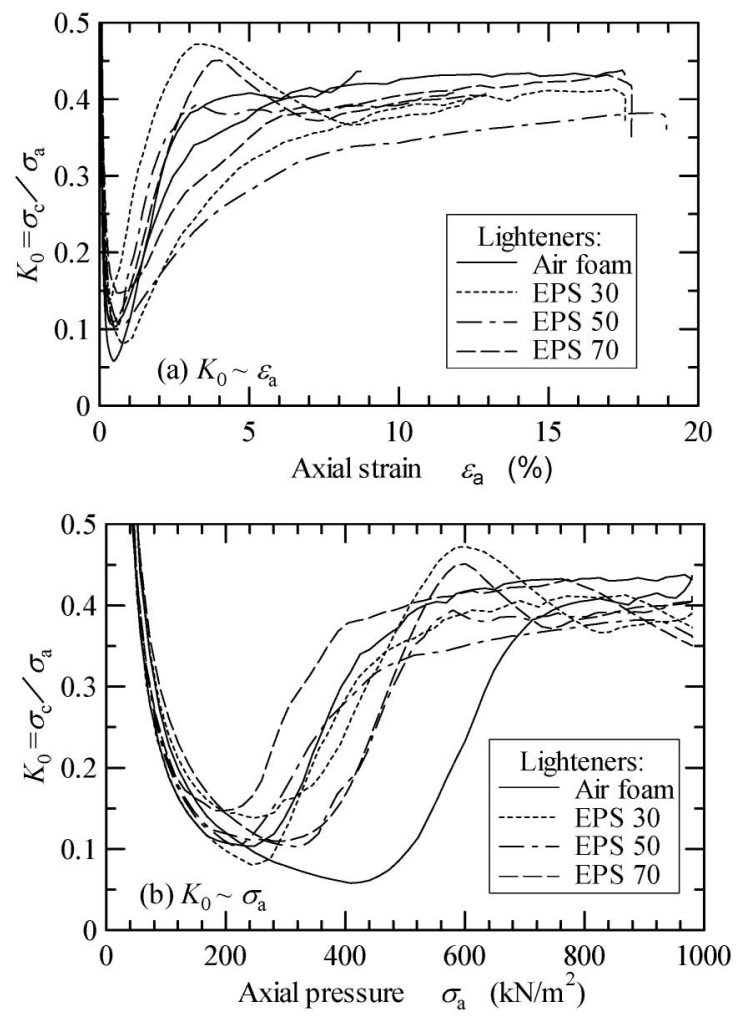

Fig. 33. $K_{0}$ value varying during whole consolidation process: (a) $K_{0}$ $\sim \varepsilon_{\mathrm{a}}$ relation and (b) $K_{0} \sim \sigma_{\mathrm{a}}$ relation

compressibility of the lightweight soil treated by cement is so small that nearly no deformation takes place until yielding occurs. However, once it passes beyond yield stress, compressibility increases drastically. In fact, if estimated on the basis of Fig. 32 in terms of compression index $C_{\mathrm{s}}$ and $C_{\mathrm{c}}$ for before and after yielding, it could be recognized that compressibility rises by a 100 -fold increase roughly. Such a characteristic is however important when large overburdening load is latently to be applied upon lightweight treated soil directly or indirectly. Once overburdening load exceeds consolidation 
yield pressure, a large settlement might follow in, unexpectedly.

Figure 33 shows $K_{0}$-value plotted against axial strain and axial pressure, respectively. $K_{0}$-value exhibits minimums of about $0.1 \sim 0.15$ around axial strain of $0.5 \sim 1$ $\%$. It is also clear that these valleys appear in proximity of $200 \mathrm{kN} / \mathrm{m}^{2}$ to $500 \mathrm{kN} / \mathrm{m}^{2}$ for axial pressure, correspondent to yielding points of compression curves shown in Fig. 32.

Figure 34 compares Poisson's ratios obtained from unconsolidated undrained compression (UU test) and $K_{0^{-}}$ consolidation. Poisson's ratio through $K_{0}$-consolidation here is calculated with $v=K_{0} /\left(1+K_{0}\right)$. The actual values of Poisson's ratios are somewhat different from each other, but they vary in a consistent tendency. Table 4 clarifies the different conditions of UU test and $K_{0}$-consolidation, comparing effects on the determination of
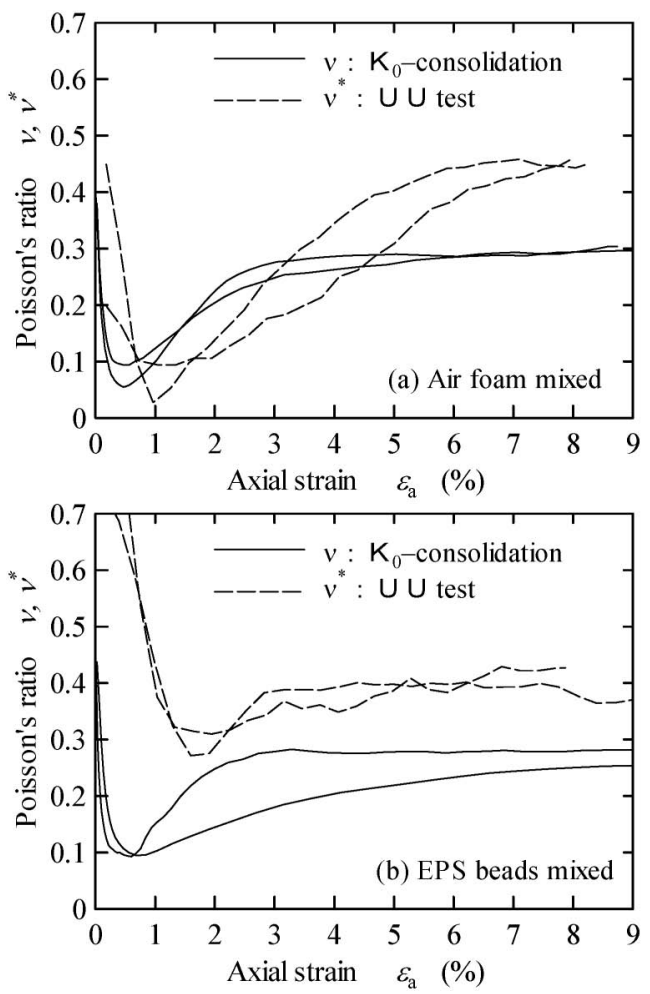

Fig. 34. Comparison of Poisson's ratios based on $K_{0}$ test and UU test
Poisson's ratio $v$ between the two different tests.

From the results in Fig. 34, Poisson's ratio could be evaluated with a minimum of $v=0.1 \sim 0.2$ near axial strains of $1 \%$ to $2 \%$, and ultimate value as $v=0.3 \sim 0.4$ at extreme large strains.

\section{CONCLUSIONS}

Lightweight treated soil is a newly developed geomaterial with its unit weight and compressive strength being artificially controlled. This technology has been validated adequate in port and harbor engineering where large quantities of dredged soft clay take place frequently. One distinct feather concerning applications to coastal areas is underwater deployment. The challenge to cast lightweight treated soil below water surface involves careful unit weight control to avoid from buoying up, and at the same time it becomes important to make clear the effects on mechanical behaviors due to considerable water pressures.

A series of lightweight treated samples were prepared on the basis of dredged clay, mixed with designed proportion of cement and lightener, either air foam or EPS beads. Unit weight was set at $12 \mathrm{kN} / \mathrm{m}^{3}$, and compressive strength was targeted at $200 \mathrm{kN} / \mathrm{m}^{2}$ or $400 \mathrm{kN} / \mathrm{m}^{2}$. The samples underwent pressured curing under various water pressures ranging from $50 \mathrm{kN} / \mathrm{m}^{2}$ to $300 \mathrm{kN} / \mathrm{m}^{2}$. Unconsolidated undrained shear tests were performed on them by use of modified triaxial apparatus, in which volumetric changes were detected. In addition, $K_{0}$-consolidation tests were also conducted on the samples similarly prepared but cured under humid atmosphere circumstance. Conclusions based on the present experimental study could be drawn as follows:

1) The pressured curing circumstance doesn't inhibit the development of compressive strength, defined as maximal deviator stress $\left(\sigma_{\mathrm{a}}-\sigma_{\mathrm{c}}\right)_{\max }$, although it is inevitable that the high water pressures compress lightener and consequently incur a certain increment in unit weight. As a secondary effect, compressive strength tends to increases with curing pressure for air foam mixed samples. However, no similar increasing tendency but a minimal strength showed up at curing pressure of $200 \mathrm{kN} / \mathrm{m}^{2}$ in EPS beads mixed

Table 4. Comparison of UU test and $K_{0}$-consolidation as concerns of Poisson's ratio $v$

\begin{tabular}{|c|c|c|c|}
\hline & UU test & $K_{0}$-consolidation & Comments concerning $v$-value \\
\hline $\begin{array}{l}\text { Curing } \\
\text { conditin }\end{array}$ & $\begin{array}{l}\text { - Underwater pressured. } \\
\text { - Saturated, fully absorption with water. } \\
\text { - Volume proportion of lightener decr- } \\
\text { eased with water pressure. (ref. Fig. 16) }\end{array}$ & $\begin{array}{l}\text { - Under humid atomsphere. } \\
\text { - Partially saturated. } \\
\text { - Volume proportion of lightener remai- } \\
\text { ned unchanged. }\end{array}$ & $\begin{array}{l}\text { UU specimens incline to yield lateral } \\
\text { strain as axial strain is exerted. }\end{array}$ \\
\hline $\begin{array}{l}\text { Draining } \\
\text { conditin }\end{array}$ & $\begin{array}{l}\text { - Undrained: pore water expelling out of } \\
\text { the specimen is not allowed. } \\
\text { - } v=0.5 \text { if lightener and cement harden- } \\
\text { ing had been removed. }\end{array}$ & $\begin{array}{l}\text { - Drained: pore water expelling out of } \\
\text { the specimen is prompted. } \\
\text { - } v \fallingdotseq 0.3 \text { even those effects had been re- } \\
\text { moved for } K_{0} \fallingdotseq 0.5 \text {. }\end{array}$ & $\begin{array}{l}\text { UU test is likely to show larger } v \text {-value } \\
\text { than } K_{0} \text {-consolidation. }\end{array}$ \\
\hline $\begin{array}{l}\text { Determining } \\
\text { method }\end{array}$ & Direct measuring of $\Delta \varepsilon_{\mathrm{a}}$ and $\Delta \varepsilon_{\mathrm{r}}$. & $\begin{array}{l}\text { Indirectly measuring of } K_{0} \text {, which is inter- } \\
\text { preted to } v \text {. }\end{array}$ & Effect on $v$-value is unclear. \\
\hline
\end{tabular}


cases, probably owning to the creep nature of EPS beads. Meanwhile, it seems that the added cell pressure plays a trivial role during shearing process. As sheared to ultimate states with axial strain large enough, the effective stress paths approach towards the critical state line, roughly coinciding with what is identified for Kawasaki clay, the source soil.

2) Secant modulus $E_{50}$ greatly depended on confining cell pressure, normalized as $\left(\sigma_{\mathrm{c}} / q_{\max }\right)$. Providing the relative cell pressure is less than 0.5 , the effect of cell pressure on modulus could be overlooked, and the results based on unconfined compression tests are available for practical purposes. When the relative cell pressure is larger than 0.5 , the effect of large pressure should be taken into account.

3) Poisson's ratio $v$ or $v^{*}$, defined as either lateral/axial strain ratio or their increment ratio, varies to wide ranges, far from a constant parameter. It shows minimal values near 0.1 to 0.2 around axial strains of $1 \%$ to $2 \%$, and tended to converge to ultimate value about 0.4 at sufficient large strains. Poisson's ratio based on undrained shear tests and that calculated from $K_{0}$ value obtained by the $K_{0}$-consolidation tests were compared. It was found that they are in consistent tendency with each other, except that undrained shear tests incline to yield larger values than that of $K_{0}$-consolidation tests.

4) $K_{0}$-consolidation tests were conducted on modified triaxial apparatus by controlling cell pressure without lateral strain's occurring. $K_{0}$ values obtained from the tests decline to as small as 0.1 to 0.15 around axial strain of $0.5 \sim 1 \%$, corresponding to consolidation yield points. The small $K_{0}$ values imply a significant reduction of earth pressure on acting caisson walls.

The compression curves revealed that the compressibility increases drastically by some 100-fold when comparing before and after yielding for lightweight treated soil. This result implies the importance of not overloading lightweight treated soil by its compressive strength; otherwise an unexpected large settlement is likely to take place.

\section{ACKNOWLEDGEMENTS}

The present study had been conducted as a part of the research project on "Development of Lightweight Geomaterials for Port and Harbor Development", which was organized by Port and Airport Research Institute (PARI). The authors express their great gratitude to all those who joined the projects.

\section{REFERENCES}

1) Kikuchi, Y., Umehara, Y., Uchiyama, Y., Gotou, T. and Ogata, H. (1994): Properties of lightweight geo-material mixed with expanded resin beads (Part 2), Effect of curing condition for lightweight geo-material, Proc. 29th Annual Meeting on Geotechnical Engineering, 2391-2392 (in Japanese).

2) Pradhan, T., Hirano, Y. and Tabata, K. (1994): Measurement of $K_{0}$ value of sandy soil lightweight treated with EPS beads, Proc. 29th Annual Meeting on Geotechnical Engineering, 2393-2394 (in Japanese).

3) Satoh, T., Tsuchida, T., Mitsukuri, K. and Hong, Z. (2001): Field placing test of lightweight treated soil under seawater in Kumamoto Port, Soils and Foundations, 41(5), 145-154.

4) Tanaka, M., Sato, S., Yoshida, Y., Morida, H. and Takahashi, H. (1994): Properties of lightweight geo-material make of dredged slurry with air foam (Part 2), Effect of curing condition for lightweight geo-material, Proc. 29th Annual Meeting on Geotechnical Engineering, 2417-2418 (in Japanese).

5) Tsuchida, T., Takeuchi, D., Okumura, T. and Kishida, T. (1996): Development of light-weight fill from dredgings, Proc. 2nd International Conference on Environmental Geomechanics, 1, 415-420.

6) Tsuchida, T., Yokoyama, K., Mizukami, J., Shimizu, K. and Sakai, J. (1996): Field test of light-weight geomaterials for harbor structures, Technical Notes of Report of PARI, (833), 28 (in Japanese).

7) Tsuchida, T., Wako, T., Kikuchi, Y., Azuma, T. and Shinsya, H. (1997a): Fluidity and material properties of light-weight treated soil casted underwater, Technical Notes of Report of PARI, (865), 27 (in Japanese).

8) Tsuchida, T., Wako, T., Matsushita, H. and Yoshiwara, M. (1997b): Evaluation of washout resistance of light-weight treated soil cast underwater, Technical Notes of Report of PARI, (884), 28 (in Japanese).

9) Tsuchida, T. (1999): Development and use of foamed treated soil in port and airport project, Report of PARI, 38(2), 131-167 (in Japanese).

10) Tsuchida, T., Kikuchi, Y., Fukuhara, T., Wako, T. and Yamamura, K. (1999): Slice method for earth pressure analysis and its application to light-weight fill, Technical Notes of Report of $P A R I$, (924), 23 (in Japanese).

11) Tsuchida, T. and Kang, M. S. (2002) : Use of Lightweight treated soil method in seaport and airport project, Proc. International Workshop on Lightweight Geomaterials, IW-LGM2002, 215-228. 